\title{
Influence of Preoxidation on High-Temperature Corrosion of a FeCrAl Alloy Under Conditions Relevant to Biomass Firing
}

Okoro, Sunday Chukwudi; Montgomery, Melanie; Jappe Frandsen, Flemming; Pantleon, Karen

Published in:

Oxidation of Metals

Link to article, DOI:

$10.1007 / \mathrm{s} 11085-017-9794-5$

Publication date:

2018

Document Version

Peer reviewed version

Link back to DTU Orbit

Citation (APA):

Okoro, S. C., Montgomery, M., Jappe Frandsen, F., \& Pantleon, K. (2018). Influence of Preoxidation on HighTemperature Corrosion of a FeCrAl Alloy Under Conditions Relevant to Biomass Firing. Oxidation of Metals, 89(1-2), 99-122. https://doi.org/10.1007/s11085-017-9794-5

\section{General rights}

Copyright and moral rights for the publications made accessible in the public portal are retained by the authors and/or other copyright owners and it is a condition of accessing publications that users recognise and abide by the legal requirements associated with these rights.

- Users may download and print one copy of any publication from the public portal for the purpose of private study or research.

- You may not further distribute the material or use it for any profit-making activity or commercial gain

- You may freely distribute the URL identifying the publication in the public portal 


\title{
Influence of preoxidation on the high temperature corrosion of a FeCrAl alloy under conditions relevant to biomass firing
}

Sunday Chukwudi Okoro ${ }^{1}$, Melanie Montgomery ${ }^{1}$, Flemming Jappe Frandsen ${ }^{2}$, Karen Pantleon ${ }^{1}$

${ }^{1}$ Department of Mechanical Engineering, Technical University of Denmark (DTU), 2800 Kongens Lyngby, Denmark.

${ }^{2}$ CHEC Research Centre, Department of Chemical and Biochemical Engineering, DTU, 2800 Kongens Lyngby, Denmark.

\begin{abstract}
Preoxidation of a commercial FeCrAl alloy (Kanthal APM) was evaluated as a surface modification approach to reduce alkali chloride induced corrosion during biomass firing in power plants. Samples of the alloy preoxidized at $900{ }^{\circ} \mathrm{C}$ in $\mathrm{O}_{2}$ or $\mathrm{O}_{2}+10$ vol $\% \mathrm{H}_{2} \mathrm{O}$, and at $1100{ }^{\circ} \mathrm{C}$ in $\mathrm{O}_{2}$, were coated with $\mathrm{KCl}$ and exposed at $560{ }^{\circ} \mathrm{C}$ to a gas mixture comprising of $12 \mathrm{vol} \% \mathrm{CO}_{2}, 6$ vol \% $\mathrm{O}_{2}, 3$ vol \% $\mathrm{H}_{2} \mathrm{O}, 400 \mathrm{ppmv} \mathrm{HCl}$ and 60 ppmv SO . The oxide formed at $1100{ }^{\circ} \mathrm{C}$ showed no reactivity with the corrosive species. In contrast, all samples preoxidized at $900{ }^{\circ} \mathrm{C}$ suffered severe attack, resulting in formation of $\mathrm{Fe}, \mathrm{Cr}$ and $\mathrm{Al}$ containing corrosion products in a heterogeneous morphology, similar to non-preoxidized samples. The observed differences with respect to the degree of corrosion attack on the preoxidized samples are discussed in terms of the composition and thickness of the different types of $\mathrm{Al}_{2} \mathrm{O}_{3}$ layers obtained by the preoxidation treatment.
\end{abstract}

Keywords: FeCrAl alloy, Preoxidation, High temperature corrosion, KCl, Chlorination, Sulphation. 


\section{Introduction}

Combustion of biomass for power production results in the deposition of corrosive $\mathrm{K}, \mathrm{Cl}$ and $\mathrm{S}$ rich species on the superheater tubes [1,2]. These species aggravate fast corrosion of the superheaters at higher temperatures [3]. To avoid catastrophic corrosion of the superheaters, the present biomass fired boilers operate at or below a safe steam temperature limit $\left(\sim 540{ }^{\circ} \mathrm{C}\right)$. Operating at such low steam temperatures limits the efficiency of biomass fired boilers and as an alternative to lowering the operation temperature, new material solutions are needed to provide corrosion resistance at higher temperatures under biomass firing conditions.

Mechanistic understanding of high temperature corrosion under biomass firing conditions is necessary to find alternative superheater materials. From previous studies [4-8], it has been recognized that high $\mathrm{Cr}$ alloyed steels, that conventionally form a protective surface layer under oxidizing conditions, fail in alkali chloride containing environments because of: i) reactivity between alkali chloride and chromia, which consumes $\mathrm{Cr}$ from the alloy and consequently provokes the formation of a less protective Fe-rich oxide that is permeable to $\mathrm{Cl}$ species [5,7] and ii) selective attack of $\mathrm{Cr}$ and Cr-rich precipitates (possibly carbides) causing the development of a porous $\mathrm{Cr}$ depleted zone in the alloy [4]. In view of these observations, a viable approach would involve the initial formation of a protective oxide layer, which does not react with the corrosive species ( $\mathrm{KCl}$, $\mathrm{HCl}, \mathrm{SO}_{2}$, etc.) encountered in biomass fired power plants.

The potential of preoxidation for protecting superheaters from corrosion has received considerable attention under sulphidizing environments [9-12]. However, under biomass firing conditions, i.e. involving oxidizing, chlorinating and sulphidizing species, investigations with focus on the influence of preoxidation are few. Investigations $[13,14]$ involving only gaseous corrosive species $\left(\mathrm{O}_{2}, \mathrm{HCl}\right.$ and $\mathrm{SO}_{2}$ ) have highlighted some positive effects of preoxidation on reducing corrosion of the investigated metals and alloys. Similarly, exposures involving solid deposits of $\mathrm{KCl}$ have recorded beneficial effects of preoxidation [15-17]. In particular, it is important to note that the preoxidation of Al-containing alloys seems promising because the stable oxide $\left(\alpha-\mathrm{Al}_{2} \mathrm{O}_{3}\right)$ is slow growing and permits lower ionic transport relative to $\mathrm{Cr}_{2} \mathrm{O}_{3}$ [16]. Moreover, chemical reactions between $\mathrm{Al}_{2} \mathrm{O}_{3}$ and $\mathrm{KCl}$ have been reported to be less likely compared with the reactivity between $\mathrm{Cr}_{2} \mathrm{O}_{3}$ and $\mathrm{KCl}$ [18]. However, assuming that the alloy contains enough $\mathrm{Al}$, which can diffuse towards the surface to form a layer of $\mathrm{Al}_{2} \mathrm{O}_{3}$, it is also important to note that the protective nature of the oxide layer for subsequent exposure to biomass firing conditions will depend on the preoxidation environment and the temperature, because both parameters affect the evolution and stability of different $\mathrm{Al}_{2} \mathrm{O}_{3}$ polymorphs [19-25].

To explore the potential of $\mathrm{Al}_{2} \mathrm{O}_{3}$ to protect Al-containing alloys from corrosion, the present work investigates both the formation of $\mathrm{Al}_{2} \mathrm{O}_{3}$ and its effect on the high temperature corrosion of a commercial FeCrAl alloy (Kanthal APM) under laboratory conditions mimicking biomass firing. 


\section{Experimental}

\subsection{Material}

A tube of the commercial FeCrAl alloy (Kanthal APM) with the composition given in Table 1 was employed for the experiments. Rings of $4 \mathrm{~mm}$ thickness were cut from the tube using a precision cutoff machine (Struers, Accutom-50). These rings were further sectioned into pieces to obtain arcshaped specimens with external arc length of $21.4 \mathrm{~mm}$ which were ultrasonically degreased and dried in acetone and ethanol. For preoxidation as well as corrosion exposure, the samples were used in the as-cut condition without further surface preparation since it has been reported [26] that the nature of sample preparation influences the rate of oxidation.

Table 1. Chemical composition (in wt \%) of Kanthal APM as specified by the manufacturer, Sandvik. Values in parenthesis were measured by energy dispersive X-ray spectroscopy.

\begin{tabular}{lllllll}
\hline Fe & Cr & Al & Si & Mn & C & $\begin{array}{l}\text { Reactive } \\
\text { elements }\end{array}$ \\
\hline Bal. & $\leq 23.5(22.7)$ & $5.8(6.0)$ & $\leq 0.7(0.4)$ & $\leq 0.4$ & $\leq 0.08$ & Y, Hf, Zr \\
\hline
\end{tabular}

\subsection{Preoxidation and high temperature corrosion exposure}

Preoxidation was carried out in a horizontal tube furnace applying different conditions to investigate the effect of both the preoxidation atmosphere $\left(\mathrm{O}_{2}\right.$ with or without $\left.\mathrm{H}_{2} \mathrm{O}\right)$ and temperature $\left(900{ }^{\circ} \mathrm{C}\right.$ and $1100{ }^{\circ} \mathrm{C}$ ). The following conditions were used:
i) $\quad \mathrm{O}_{2}$ at $900{ }^{\circ} \mathrm{C}$,
ii) $\mathrm{O}_{2}+10 \mathrm{vol} \% \mathrm{H}_{2} \mathrm{O}$ at $900{ }^{\circ} \mathrm{C}$
iii) $\quad \mathrm{O}_{2}$ at $1100{ }^{\circ} \mathrm{C}$.

Samples for each preoxidation experiment were placed parallel to the gas flow in the furnace and isothermally treated for the period of $168 \mathrm{~h}$. The gas flow rate in each case was $300 \mathrm{~mL} / \mathrm{min}$. Afterwards, they were cooled to room temperature in the furnace under a flow of the applied gas.

For evaluating the effect of the preoxidation on corrosion resistance, the preoxidized samples as well as non-preoxidized samples (as reference) were subjected to an atmosphere containing $12 \mathrm{vol} \% \mathrm{CO}_{2}$, 6 vol\% $\mathrm{O}_{2}, 400 \mathrm{ppmv} \mathrm{HCl}$ and $60 \mathrm{ppmv} \mathrm{SO}_{2}$ at a temperature of $560^{\circ} \mathrm{C}$ for the period of 168 hours. Before the high temperature corrosion exposure, samples were coated with a deposit consisting of $\mathrm{KCl}$, which together with the applied gas atmosphere resembles conditions in the power plant. The deposit was obtained by mixing 32-63 $\mu \mathrm{m}$ sized $\mathrm{KCl}$ particles (Sigma $\geq 99 \%$ ) with iso-propanol. After drying the slurry, it left an approximately $1 \mathrm{~mm}$ thick $\mathrm{KCl}$ deposit on the surface of the samples. The samples were exposed in a corrosion test rig which consists of a gas mixing unit, a horizontal furnace and a gas cleaning unit. Details of the experimental setup are given elsewhere [27]. The gas 
mixture was passed through a water bath, to add 3 vol\% $\mathrm{H}_{2} \mathrm{O}$, before feeding into the furnace through preheated gas lines using $\mathrm{N}_{2}$ as a carrier gas. The total gas flow rate was $1000 \mathrm{~mL} / \mathrm{min}$. A minimum of 3 samples, in a given condition, were exposed to check reproducibility of the results. The samples were aligned parallel to the gas flow in the furnace. After each exposure, samples were cooled inside the furnace under a flow of the applied gas mixture.

\subsection{Characterization of preoxidized surfaces and corrosion products}

Microstructure characterization of samples after preoxidation was carried out on sample cross sections, and supplemented by plan view investigations. Non-preoxidized and preoxidized samples were mounted in an epoxy resin followed by standard metallographic preparation of the sample cross sections down to $1 \mu \mathrm{m}$ diamond suspension polishing.

The cross sections of preoxidized samples were coated with carbon prior to investigations with scanning electron microscopy (SEM) and energy dispersive X-ray spectroscopy (EDS), to avoid charging of the embedded samples in the SEM. The thickness of the oxide layers was measured from SEM images of the cross sections with the help of an image analysis software (ImageJ). In addition, plan view investigations applying SEM and EDS were carried out on the preoxidized samples and further supplemented with X-ray diffraction (XRD) analysis for identification of phases in the oxide layers.

Corrosion products were characterized by both cross-section and plan view investigations. As described previously [27], the metallographic preparation of sample cross sections after corrosion exposure occurred with special care to preserve the corrosion product. Plan view investigations started on the topside and underside of the deposit which had sintered during exposure and could easily be removed to reveal the as-corroded surface, and subsequently involved successive mechanical removal of the corrosion product layers with a scalpel or SiC paper. The revealed interfaces were characterized by the complementary use of SEM, EDS and XRD. The methodology of comprehensive plan view and cross section analysis has been previously reported [28].

The SEM (FEI Inspect S or Quanta ESEM FEG with EDS system from Oxford Instruments) was operated for both imaging and chemical analysis with an acceleration voltage of $15 \mathrm{keV}$ (unless stated otherwise). Both secondary electrons (SE) and backscattered electrons (BSE) were used for imaging. For qualitative phase analysis by XRD, a Bruker AXS D8 Discover diffractometer equipped with Cr$\mathrm{K} \alpha$ radiation was used. All XRD measurements were carried out in grazing incidence mode (GIXRD) with a counting time of $10 \mathrm{~s}$ per step size of $0.03^{\circ} 2 \theta$. A fixed incidence angle $(\gamma)$ of $2^{\circ}$ was used for oxide phase identification after preoxidation, which corresponds to a uniform X-ray penetration depth of about $1 \mu \mathrm{m}$. XRD investigations on samples after corrosion exposures employed $\gamma=5^{\circ}$, thus, covering slightly larger depths, which combined with subsequent mechanical removal, prevents averaging over the expected differences in chemical and phase composition below the surface. 
For microstructure analysis of the FeCrAl bulk alloy before and after preoxidation as well as after corrosion exposure, polished cross-sections were etched with glyceregia and investigated using reflected light optical microscopy (LOM).

\section{Results}

\subsection{Preoxidation under different gas atmospheres $\left(\mathrm{O}_{2}, \mathrm{O}_{2}+10\right.$ vol\% $\left.\mathrm{H}_{2} \mathrm{O}\right)$ and temperatures $\left(900^{\circ} \mathrm{C}, 1100^{\circ} \mathrm{C}\right)$}

The microstructure of the oxide formed after preoxidation in $\underline{\mathrm{O}}_{2} \underline{\text { at }} 900 \stackrel{\circ}{\mathrm{C}} \underline{\mathrm{C}}$ is shown in Figure 1 , from which features exhibiting globular (insert in Figure 1a) and platelet (Figure 1b) morphologies can been seen. Figure 1c showing the cross section of the sample reveals a thin oxide of about $0.5 \mu \mathrm{m}$ thickness (Figure 2), which predominantly contains $\mathrm{Al}$ and $\mathrm{O}$ as revealed by EDS.

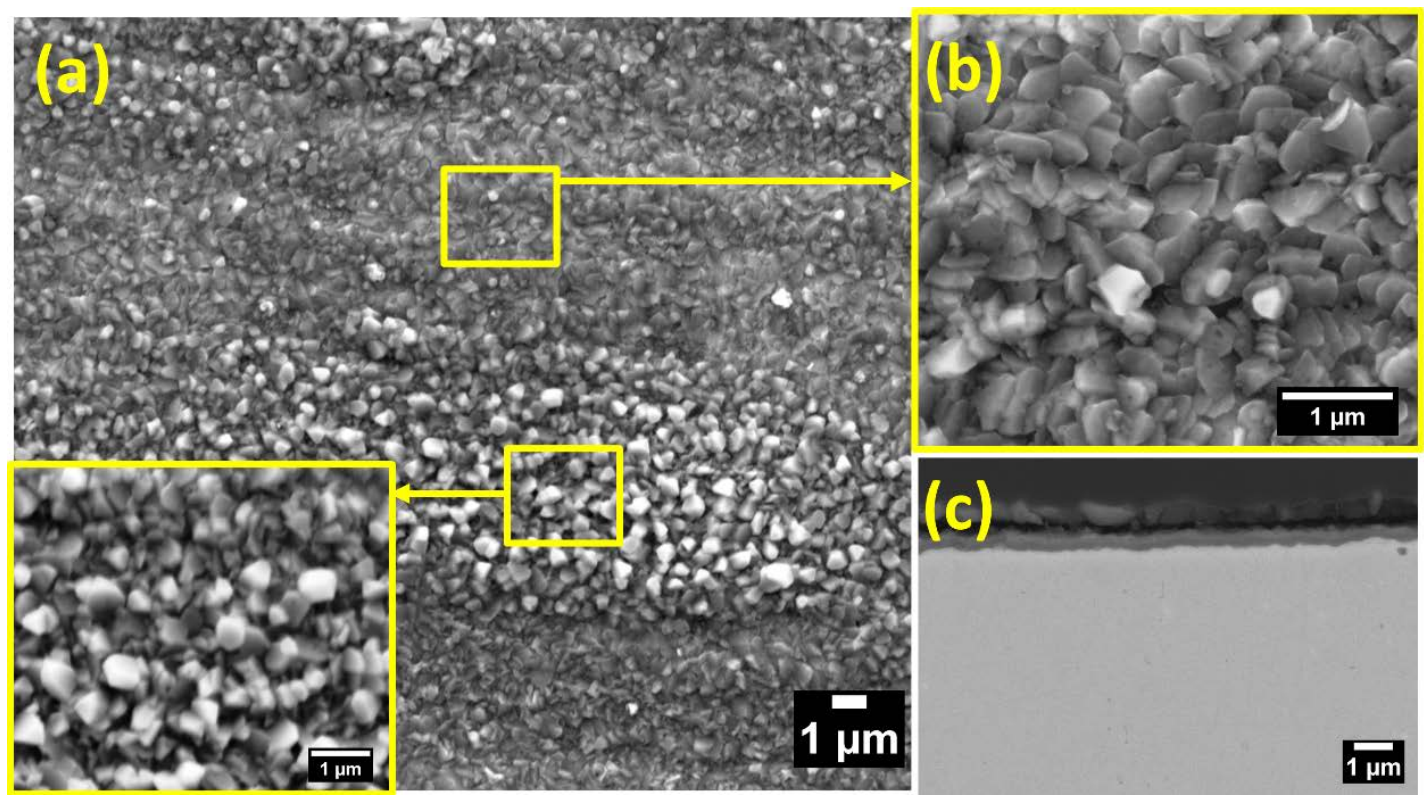

Figure 1. Oxide morphology resulting from preoxidation in $\mathrm{O}_{2}$ at $900{ }^{\circ} \mathrm{C}$. (a, b) SE micrographs (acceleration voltage, $10 \mathrm{keV}$ ) showing plan view morphology of the sample surface, (c) BSE micrograph showing a cross section of the sample.

Changing the gas atmosphere by adding 10 vol\% $\mathrm{H}_{2} \mathrm{O}$ during preoxidation $\left.\underline{\mathrm{O}}_{2} \underline{+}+10 \mathrm{vol} \% \mathrm{H}_{2} \underline{\mathrm{O}}\right)$ at $\underline{900^{\circ} \mathrm{C}}$, does not considerably affect the morphology and composition of the oxide (Figure 3), but results in local thickness variations with a slightly higher thickness (about $0.7 \mu \mathrm{m}$ on average) of the preoxidized layer (Figure 2). The corresponding oxide surface and cross section as shown in Figure 3, reveal similar morphology (platelets and globular features, Figure 3b, c) and composition (Al enriched surface) as the oxide obtained after preoxidation at $900^{\circ} \mathrm{C}$ in $\mathrm{O}_{2}$ (cf. Figure 1). In contrast to preoxidation in $\mathrm{O}_{2}$, local enrichment of $\mathrm{Cr}$ was observed within the oxide adjacent the oxide/alloy interface where thicker oxides formed (Figure 3e). 


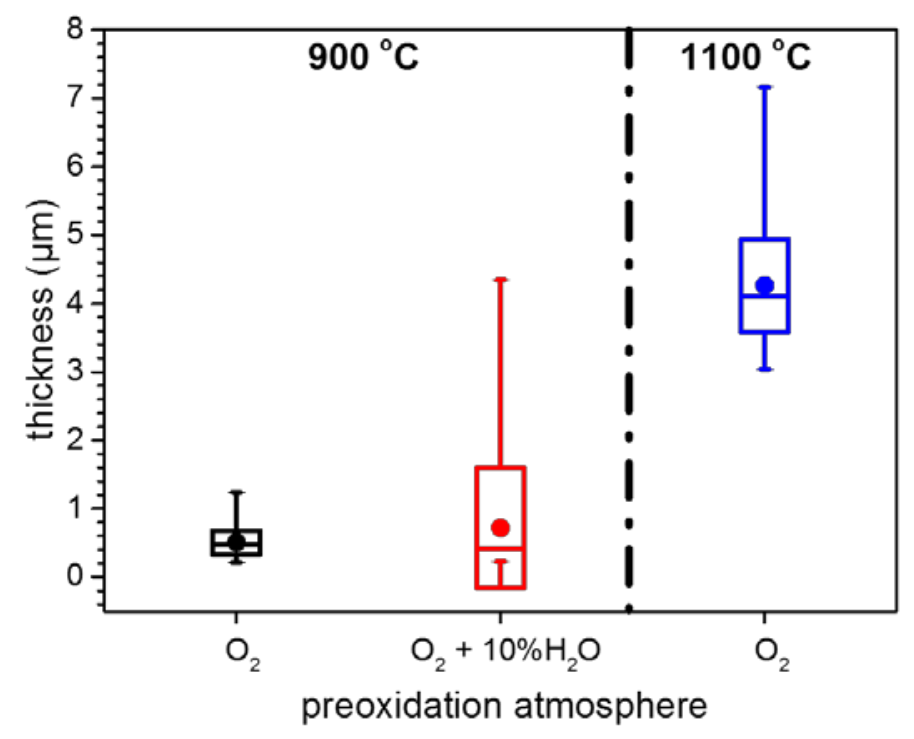

Figure 2. Thickness of oxide layers after preoxidation under different gas atmospheres and temperatures. A minimum of 50 measurements were employed to obtain the statistical distribution of the oxide layer thickness. The round dots represent the mean thickness, while the vertical extensions depict the maximum and minimum oxide thickness. The box edges represent the standard deviation of the mean, and the horizontal bar inside each box depicts the position of $50 \%$ of the distribution.

Compared to the minor effect of the gas atmosphere during pre-oxidation at $900^{\circ} \mathrm{C}$ as described above, an increase of the temperature to $1100^{\circ} \mathrm{C}$ was found to strongly affect the thickness of the oxide. After preoxidation in $\underline{\mathrm{O}}_{2} \underline{a t}_{1100}{ }^{\circ} \mathrm{C}$, thickness measurements as well as microscopic cross section analysis with EDS measurements (Figure 4) reveal an about $4.3 \mu \mathrm{m}$ thick oxide layer (Figure 2 ), which fully covers the surface. In addition, the platelet features observed on samples preoxidized at $900^{\circ} \mathrm{C}$ (Figures $1 \mathrm{~b}$ and $3 \mathrm{~b}$ ) were absent on samples preoxidized at $1100^{\circ} \mathrm{C}$. Instead, the oxide contained features with a globular morphology (Figure 4b). 

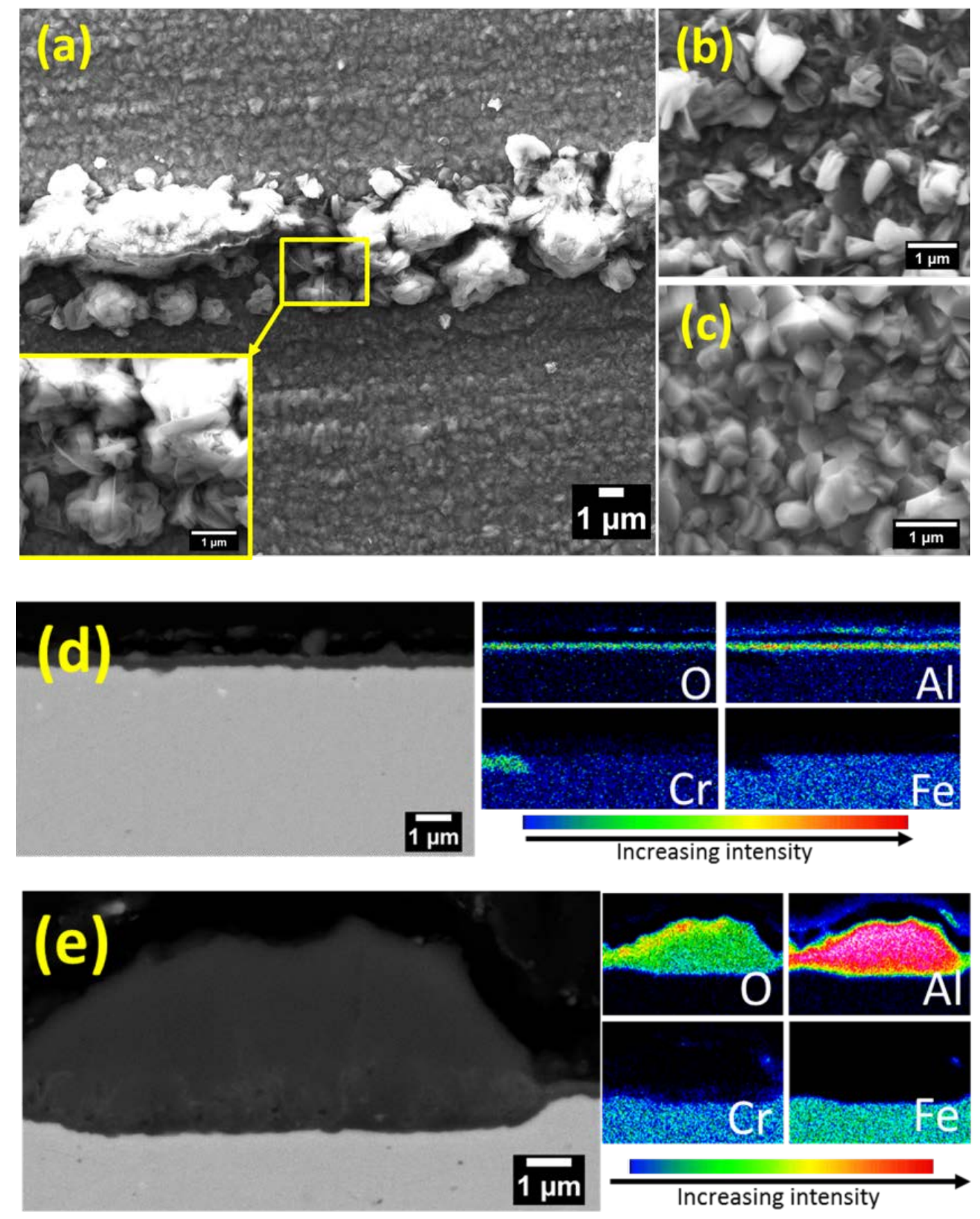

Figure 3. Oxide morphology resulting from preoxidation in $\mathrm{O}_{2}+10 \mathrm{vol} \% \mathrm{H}_{2} \mathrm{O}$ at $900{ }^{\circ} \mathrm{C}$. (a-c) $\mathrm{SE}$ micrographs (acceleration voltage, $10 \mathrm{keV}$ ) showing plan view morphology of the oxide. (d, e) BSE micrographs and EDS maps showing the cross-section and elemental composition of different regions of the oxide. 


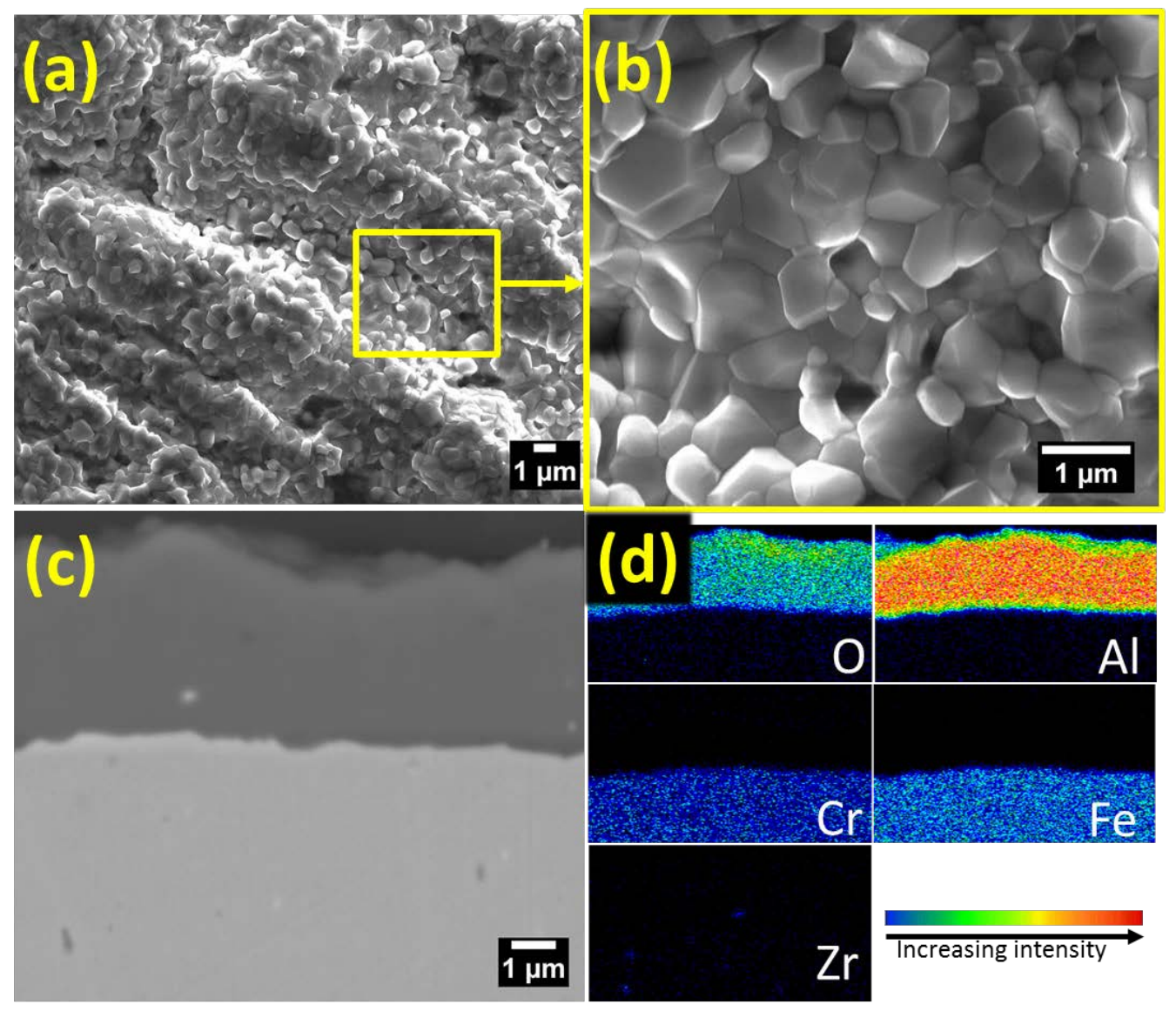

Figure 4. Oxide morphology resulting from preoxidation in $\mathrm{O}_{2}$ at $1100{ }^{\circ} \mathrm{C}$. (a, b) SE micrographs (acceleration voltage, $10 \mathrm{keV}$ ) of the oxide in plan view of the sample surface. (c) BSE micrograph showing the cross-section and (d) elemental composition of the oxide.

The diffraction patterns obtained from grazing incidence X-ray diffraction measurements on samples subjected to the different preoxidation treatments are shown in Figure 5. For the samples that were preoxidized at $900^{\circ} \mathrm{C}$, phase analysis confirmed the presence of the thermodynamically stable phase $\alpha-\mathrm{Al}_{2} \mathrm{O}_{3}$ [Joint Committee on Powder Diffraction Standards (JCPDS) card: 46-1212] with a rhombohedral crystal lattice. Also $\mathrm{Cr}_{2} \mathrm{O}_{3}$ [JCPDS card: 38-1479] was detected on these samples independent of the applied gas atmosphere at $900^{\circ} \mathrm{C}$. However, as $\alpha-\mathrm{Al}_{2} \mathrm{O}_{3}$ and $\mathrm{Cr}_{2} \mathrm{O}_{3}$ are of the same crystal lattice, the formation of a solid solution of these oxides is possible [29-31] and the simultaneous presence of Cr-Al-oxide (( $\left.\mathrm{Al}_{0.948} \mathrm{Cr}_{0.052}\right)_{2} \mathrm{O}_{3}$, [JCPDS card: 71-0958]) is suggested from to the observed asymmetry of measured oxide peaks. 

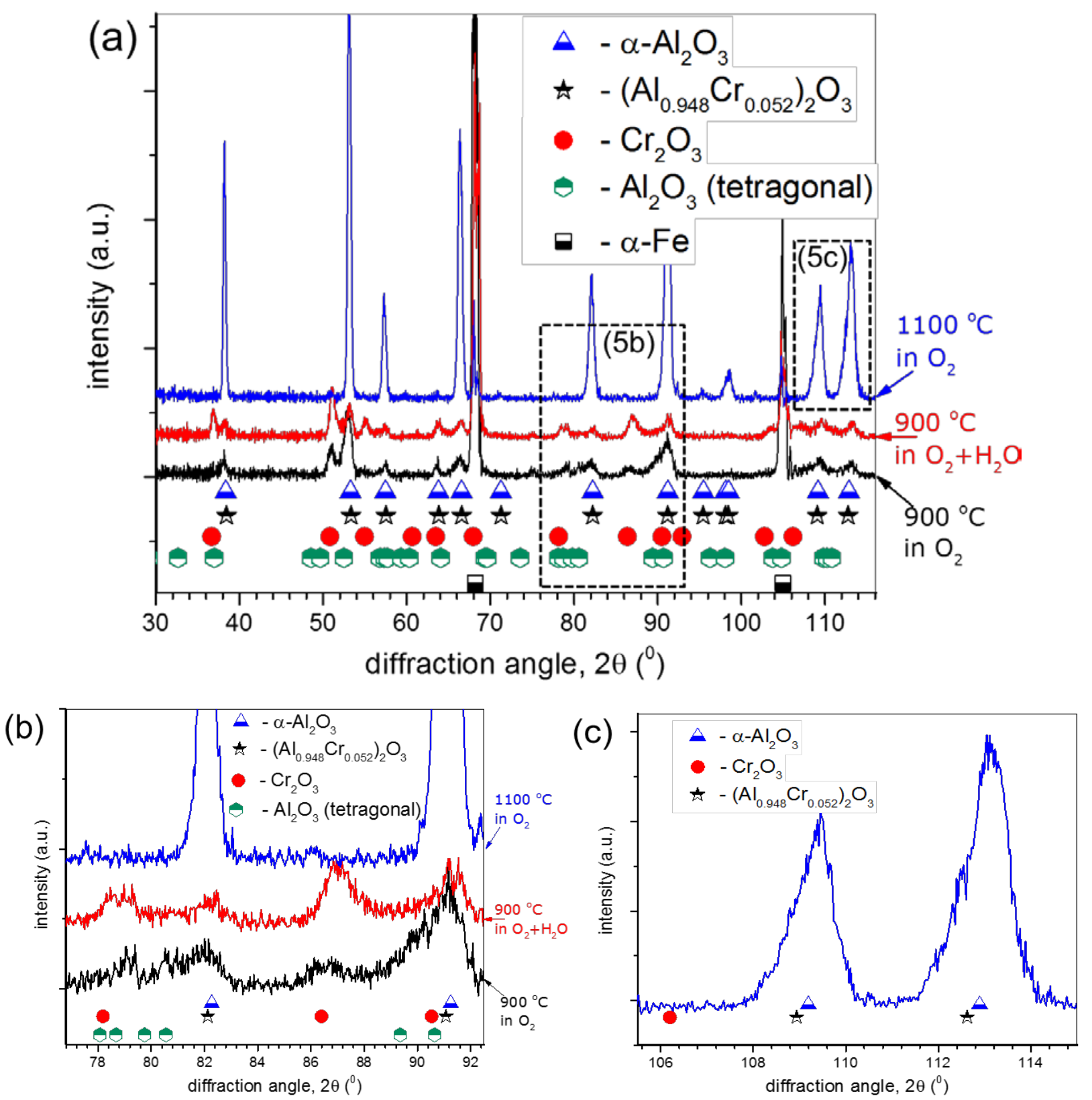

Figure 5. (a) XRD diffraction patterns measured for samples from the various preoxidation treatments. (b, c) Magnified regions of the diffraction patterns showing asymmetric peak profiles due to overlapping peaks from different phases in the preoxidation layers. Identified oxide phases are marked.

A metastable $\mathrm{Al}_{2} \mathrm{O}_{3}$ [JCPDS card: 46-1131] with a tetragonal lattice, possibly $\delta-\mathrm{Al}_{2} \mathrm{O}_{3}$ [32], was also present in the oxides formed at $900{ }^{\circ} \mathrm{C}$ and overlap of its peaks with those of $\mathrm{Cr}_{2} \mathrm{O}_{3}$, $\left(\mathrm{Al}_{0.948} \mathrm{Cr}_{0.052}\right)_{2} \mathrm{O}_{3}$ and $\alpha-\mathrm{Al}_{2} \mathrm{O}_{3}$ also contributes to the observed asymmetric profile of some $\alpha-\mathrm{Al}_{2} \mathrm{O}_{3}$ peaks as exemplified in Figure 5b. On the other hand, the oxide obtained after preoxidation in $\mathrm{O}_{2}$ at 
$1100{ }^{\circ} \mathrm{C}$ consists mainly of $\alpha-\mathrm{Al}_{2} \mathrm{O}_{3}$. However, at higher diffraction angles, peaks corresponding to the $\alpha-\mathrm{Al}_{2} \mathrm{O}_{3}$ phase also exhibit an asymmetric profile (Figure $5 \mathrm{c}$ ), which indicates the simultaneous presence of a solid solution $\left(\mathrm{Al}_{0.948} \mathrm{Cr}_{0.052}\right)_{2} \mathrm{O}_{3}$. As a result of the thin nature of these oxides, reflections from the bulk alloy ( $\alpha$-Fe [JCPDS card: $85-1410]$ ) were also recorded in all the diffraction patterns.

\subsection{Characterization of corrosion products}

\subsubsection{Corrosion of non-preoxidized samples}

Figure 6 shows the cross section of the heterogeneous corrosion product resulting from severe attack after corrosion exposure of a non-preoxidized Kanthal APM sample. From the BSE micrograph in Figure 6a, it appears that the corrosion product has grown outwards and inwards, i.e. above and below the original sample surface. The corrosion attack progressed towards the bulk alloy by grain boundary attack.

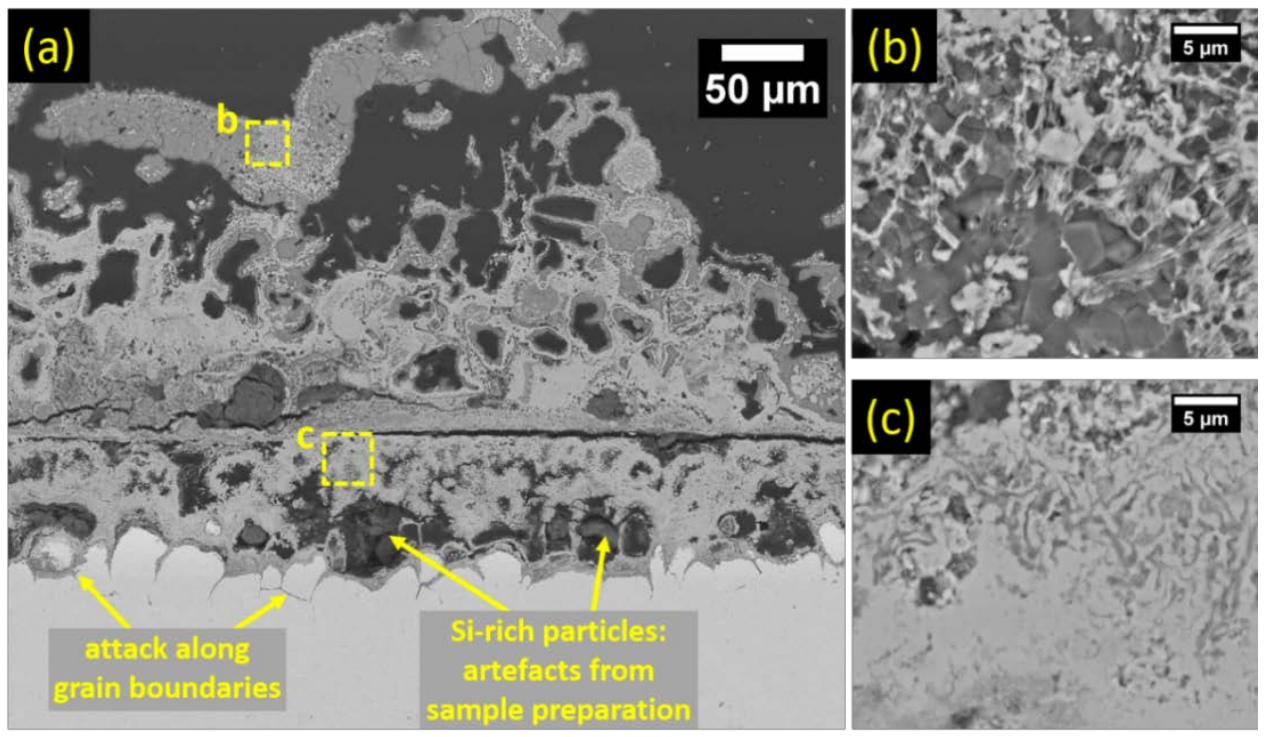

Figure 6. Corrosion of a non-preoxidized sample. (a) BSE micrograph. (b, c) Magnified images emphasizing the microstructure of the corresponding areas in (a). 

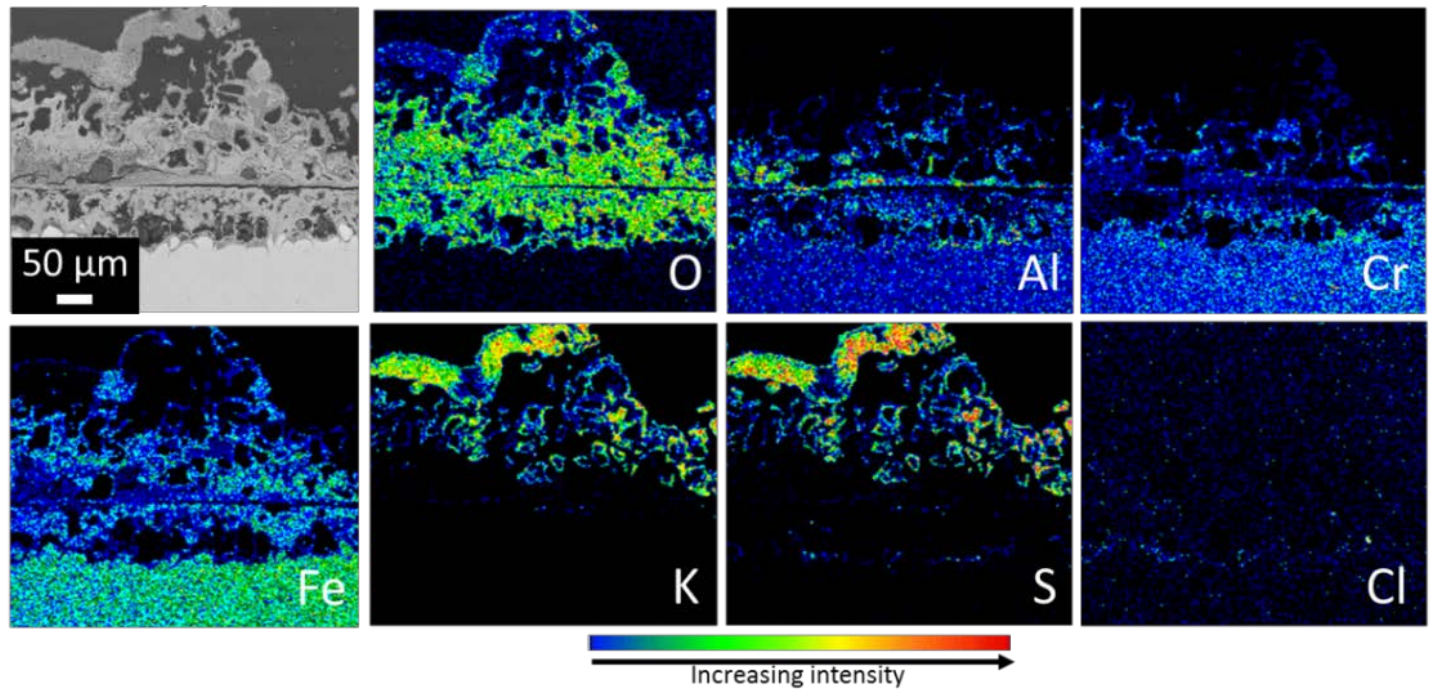

Figure 7. EDS map showing the elemental distribution in corrosion products resulting from corrosion exposure of non-preoxidized sample.

EDS maps in Figure 7 showing the elemental distribution within these corrosion products reveal that those formed above the original surface consist of a mixture of oxides of the alloying elements (Al, $\mathrm{Cr}$ and $\mathrm{Fe}$ ) with $\mathrm{K}$ (from the applied deposit) and S (from the gas atmosphere). This is supported by the contrast differences observed by microscopy (Figure 6b), which relate to the formation of oxides and sulphate (dark regions) in the micrograph. The corrosion product formed below the original surface also consists of a mixture of different phases (Figure 6c) which is revealed by EDS mapping (Figure 7) to be an oxide mixture containing $\mathrm{Al}, \mathrm{Cr}$ and $\mathrm{Fe}$. The maps also show that $\mathrm{Al}$ and $\mathrm{Cr}$ oxides are present in the regions where grain boundary attack occurred. Slight local enrichment of S and $\mathrm{Cl}$ is observed at the corrosion front.

Results from plan view characterization (Figure 8 and 9) provide more information on the morphology of the corrosion products. At the gas/deposit and deposit/corrosion product interfaces, the typical microstructures of the deposit after exposure are shown in Figures 8a and b, respectively. A distinctive observation is the accumulation of $\mathrm{K}, \mathrm{S}$ and $\mathrm{O}$ rich features, indicating the formation of $\mathrm{K}_{2} \mathrm{SO}_{4}$, around $\mathrm{KCl}$ deposit particles. The size of these $\mathrm{K}_{2} \mathrm{SO}_{4}$ accumulations is largest at the gas/deposit interface, partly obscuring identification of the $\mathrm{KCl}$ deposit particles, but is much smaller just below the surface (Figure 8a). Consistently, the smaller size of these $\mathrm{K}, \mathrm{S}$ and $\mathrm{O}$ rich accumulations also is observed at the deposit/corrosion product interface (Figure 8b) where, consequently, EDS analysis also shows the presence of $\mathrm{Cl}$ due to contribution from the deposit particles. 

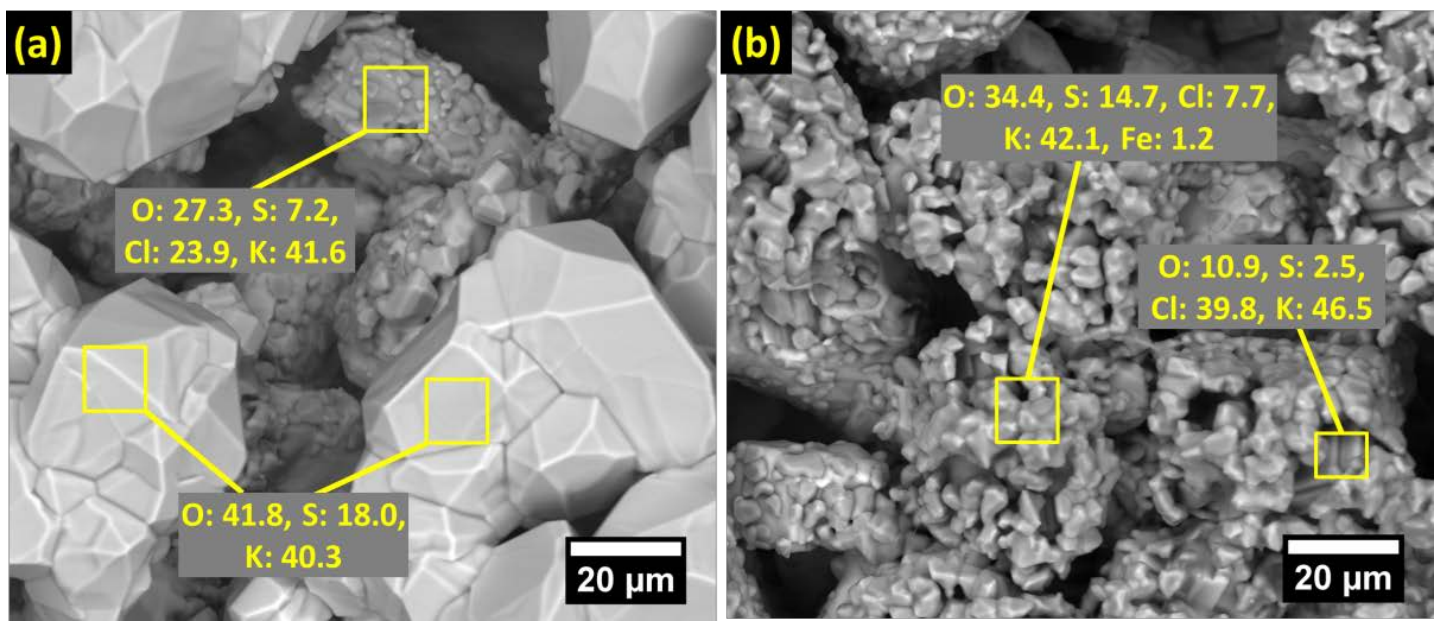

Figure 8. BSE micrographs showing the plan view microstructure of deposits at the (a) gas/deposit and (b) deposit/corrosion product interfaces after exposure of a non-preoxidized sample. Inserted EDS results are given in wt \%.

The plan view morphology of corrosion products after removal of the deposit is shown in Figure 9a, from which $\mathrm{Fe}-\mathrm{Cr}$ containing oxides with platelet morphologies are evident. With successive mechanical removal of the outer corrosion products, regions of grain boundary attack were revealed. Figure 9b shows a typical plan view microstructure of such regions. In agreement with observations on sample cross sections (Figure 7), the accompanying EDS maps (Figure 9c) reveal that $\mathrm{Al}$, Cr and $\mathrm{O}$ were present in the attacked grain boundaries. Local $\mathrm{Cl}$ accumulation is also identified around the regions of grain boundary attack.

Figure 10 shows the crystalline phases at different depths within the corrosion product as detected with XRD. At the deposit/gas interface, the presence of $\mathrm{K}_{2} \mathrm{SO}_{4}$ [JCPDS card: 70-1488] in the initial $\mathrm{KCl}$ deposit [JCPDS card: 41-1476] is revealed. This is in agreement with the observation of $\mathrm{K}, \mathrm{S}$ and $\mathrm{O}$ rich features in Figure 8a. At the surface of the corrosion product, after deposit removal, $\mathrm{Fe}_{2} \mathrm{O}_{3}$ [JCPDS card: 33-0664] and $\mathrm{FeCr}_{2} \mathrm{O}_{4}$ [JCPDS card: 34-140] were identified. No additional phase is observed with further removal of the corrosion products, until the bulk alloy was approached. Instead, the peak intensities for $\mathrm{Fe}_{2} \mathrm{O}_{3}$ and $\mathrm{FeCr}_{2} \mathrm{O}_{4}$ decreased, while those from the bulk alloy ( $\alpha$-Fe [JCPDS card: 85-1410]) increased. 


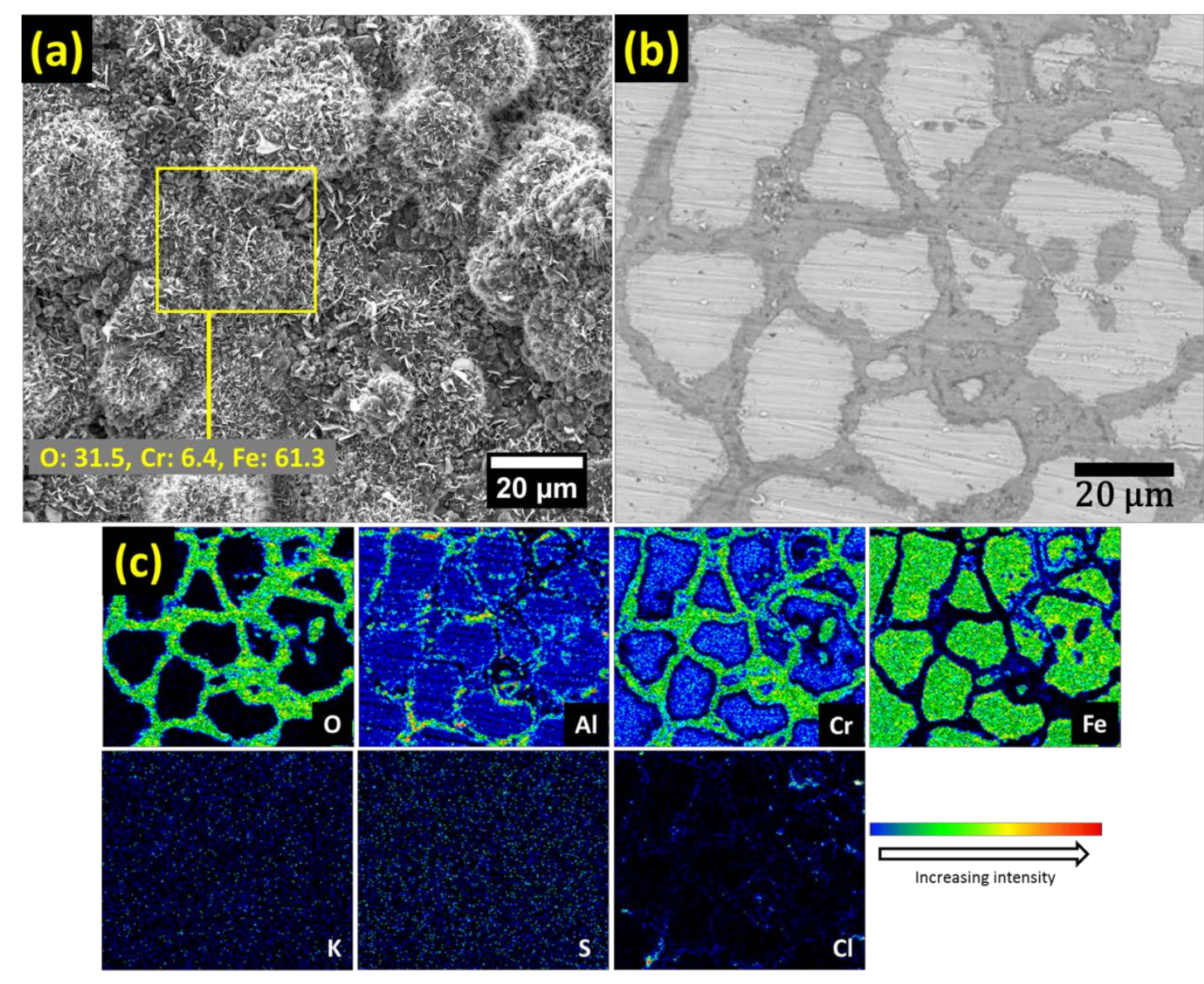

Figure 9. Selected results from plan view ‘top-down' characterization of corrosion products on a non-preoxidized sample after corrosion exposure. (a) SE micrograph showing heterogeneous Fe-rich oxide after removal of the deposit (i.e. at the corrosion product/deposit interface). (b) BSE micrograph and (c) EDS maps showing the microstructure and elemental composition of grain boundary attacked regions at the corrosion product/bulk alloy interface. Inserted EDS results in (a) are given in wt \%. 


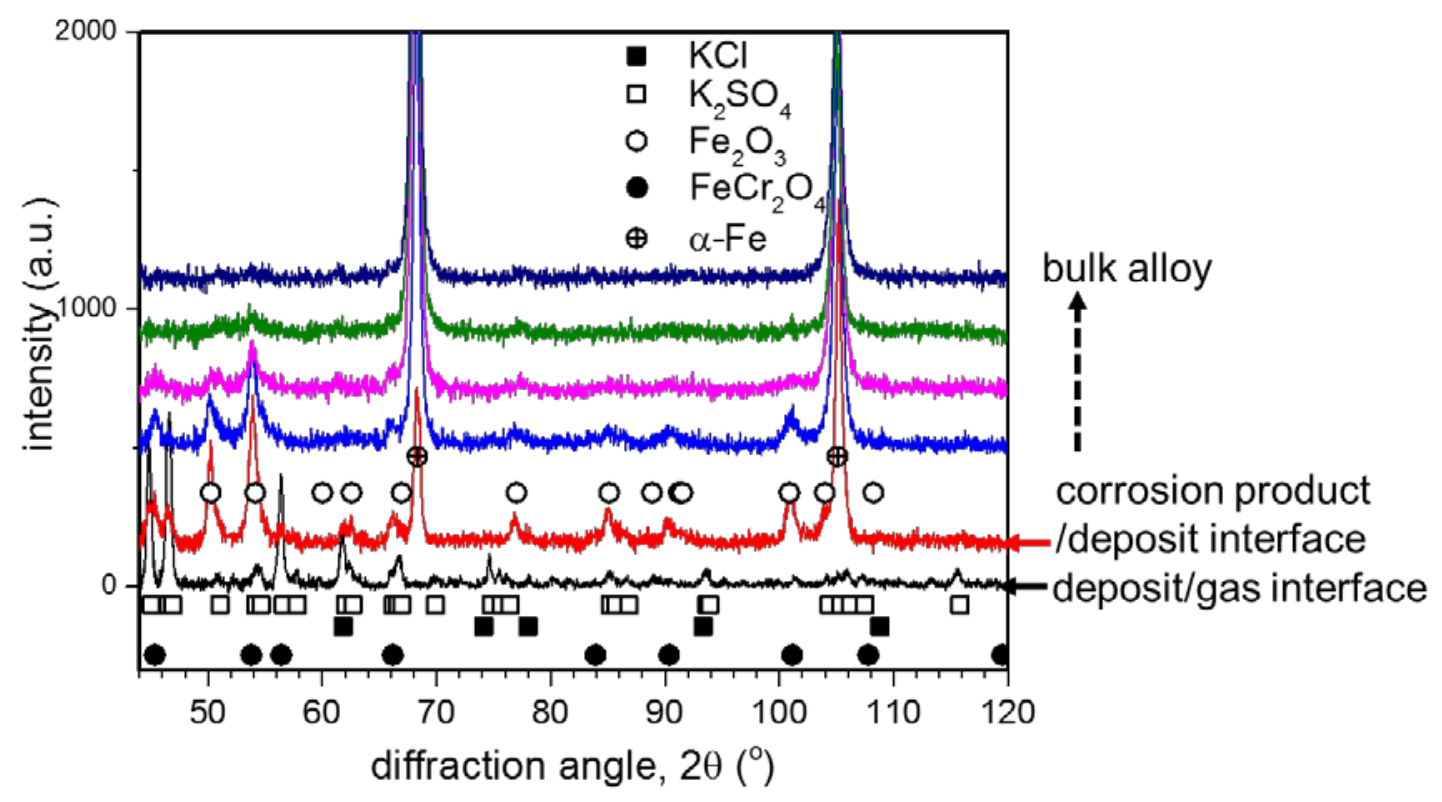

Figure 10. XRD diffractograms showing the crystalline phases on a non-preoxidized sample after corrosion exposure. The diffractograms were obtained from the indicated interfaces following successive mechanical removal.

\subsubsection{Corrosion of samples preoxidized at $900{ }^{\circ} \mathrm{C}$}

Figures 11-14 show the microstructure and chemical composition of the corrosion products formed after corrosion exposure of samples preoxidized at $900{ }^{\circ} \mathrm{C}$ in different atmospheres. Samples preoxidized in $\mathrm{O}_{2}$ at $900{ }^{\circ} \mathrm{C}$ suffered corrosion attack (Figure 11a) but to a lesser degree, compared to the non-preoxidized samples. With a composition similar to the non-preoxidized sample (cf. Figure 7), the outer corrosion products consist of an oxide mix containing Al, $\mathrm{Cr}$ and Fe (Figure $11 \mathrm{~b}$ ). $\mathrm{K}$ and $\mathrm{S}$ are also present in the upper regions of the outward grown part of the corrosion product and in addition, plan view investigations (not shown here) revealed accumulation of $\mathrm{K}_{2} \mathrm{SO}_{4}$ particles around the deposits. The inward grown corrosion product consists predominantly of Fe oxide with $\mathrm{Al}$ and $\mathrm{Cr}$ enrichment closer to the corrosion front. Corrosion attack along the alloy grain boundaries resulted in an enrichment of $\mathrm{Al}, \mathrm{Cr}$ and $\mathrm{O}$. In addition, the EDS maps in Figure 11b reveal the presence of S and $\mathrm{Cl}$ in the attacked grain boundaries. 


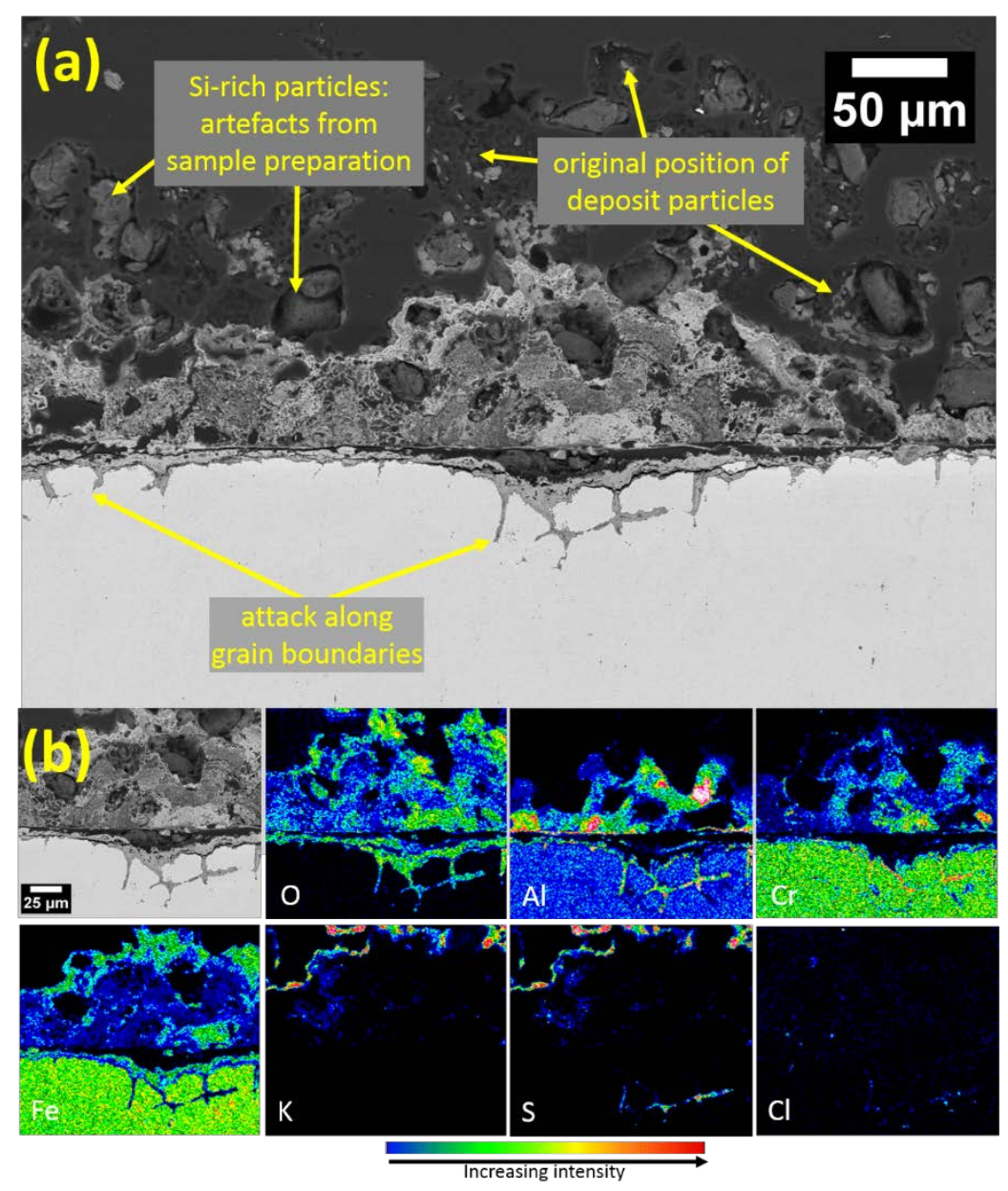

Figure 11. Corrosion of a preoxidized sample (in $\mathrm{O}_{2}$ at $900^{\circ} \mathrm{C}$ ) (a) BSE micrograph. (b) EDS map of corrosion products.

Complementary information on the morphology and composition of these corrosion products is revealed by plan view investigations as shown in Figure 12. Interestingly, the presence of an Al-rich layer was still identifiable on some regions beneath the deposit after its removal (Figure 12a). However, it is also observed that Fe-Cr containing oxides with platelet morphologies similar to the non-preoxidized samples (cf. Figure 9a) have formed beneath the initial Al-rich oxide as a result of the corrosion attack. In addition, the corrosion products after removal of the deposit consisted of Clrich protrusions (Figure 12b) which appear to grow out from the bulk alloy. The regions of grain boundary attack, as revealed by successive mechanical removal of external layers (Figure 12c), show the presence of $\mathrm{Al}, \mathrm{Cr}, \mathrm{S}, \mathrm{Cl}$ and $\mathrm{O}$ in the attacked grain boundaries, which confirms the observations on cross sections (cf. Figure 11b). The crystalline phases identified on the revealed interfaces were the same as those identified on the non-preoxidized sample (cf. Figure 10). 

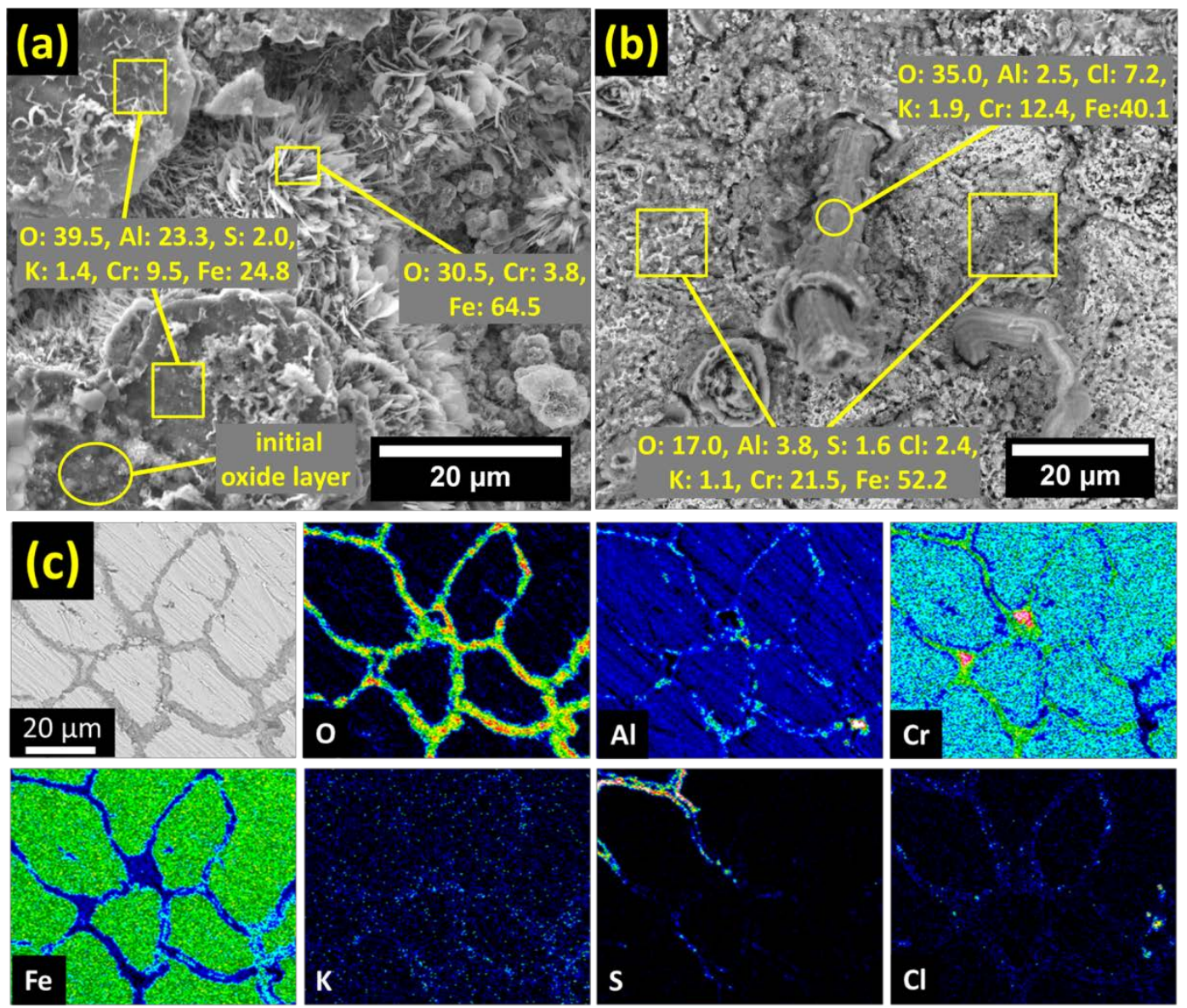

Increasing intensity

Figure 12. Selected results from plan view 'top-down' characterization of corrosion products on a preoxidized sample (in $\mathrm{O}_{2}$ at $900{ }^{\circ} \mathrm{C}$ ). (a) SE micrograph showing the heterogeneous Fe-rich oxide at the corrosion product/deposit interface. The initial oxide layer is evident on some regions. (b) Cl-rich protrusions (BSE micrograph) at the corrosion product/deposit interface. (c) BSE micrograph and EDS maps showing the microstructure and elemental composition of grain boundary attacked regions at the corrosion product/bulk alloy interface. Inserted EDS results in (a) and (b) are given in wt \%. 


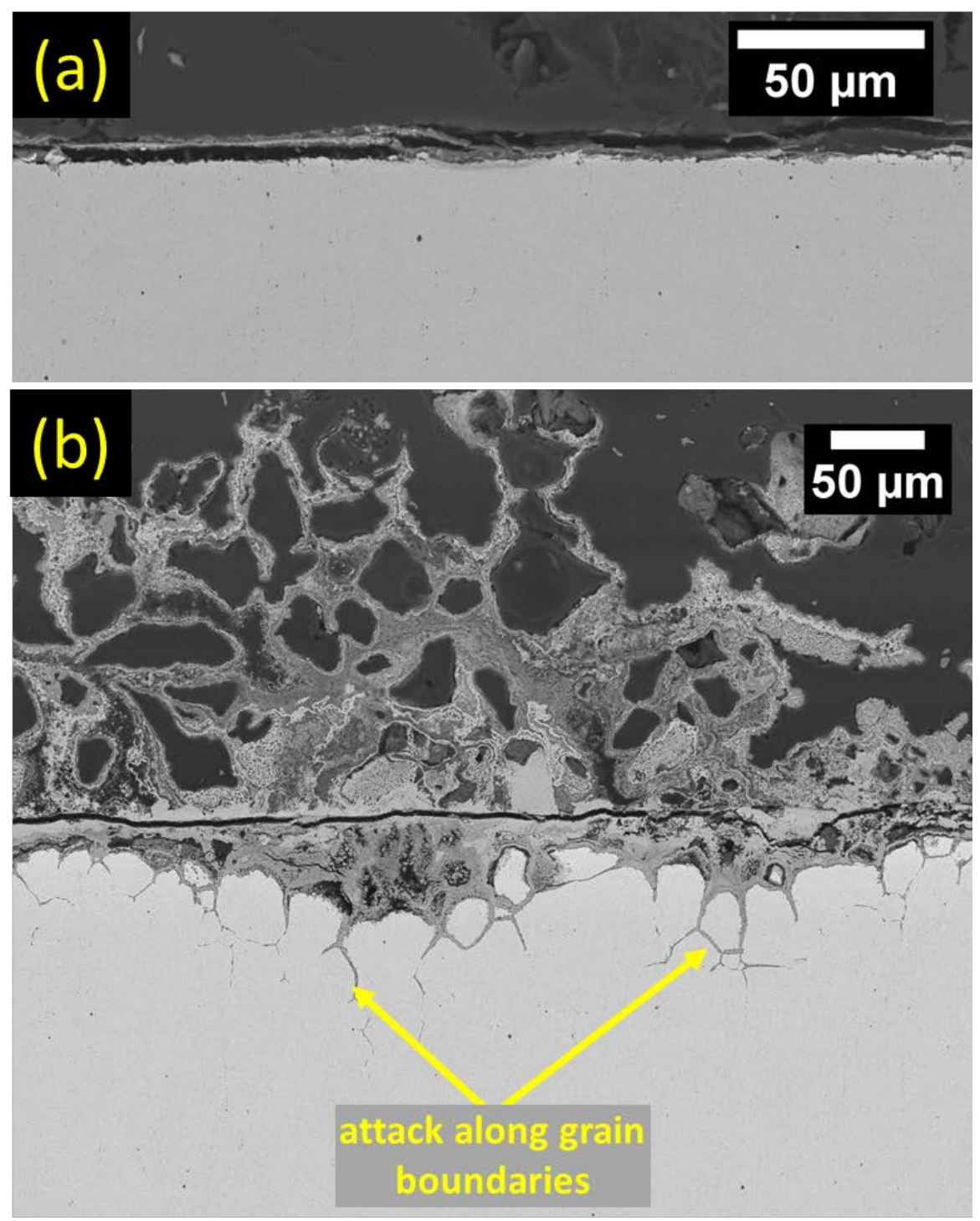

Figure 13. BSE micrographs showing the corrosion of a preoxidized sample (in $\mathrm{O}_{2}+10$ vol \% $\mathrm{H}_{2} \mathrm{O}$ at $900{ }^{\circ} \mathrm{C}$ ). (a) Regions showing insignificant corrosion attack and (b) typical microstructure of severely attacked regions.

For the samples which were preoxidized in $\mathrm{O}_{2}+10$ vol\% $\mathrm{H}_{2} \mathrm{O}$ at $900{ }^{\circ} \mathrm{C}$, Figure 13 a shows that some regions (less than $15 \%$ of the investigated cross sections) did not suffer significant corrosion attack after corrosion exposure. EDS maps in Figure 14a clearly show the presence of an Al rich layer in such regions, in addition to $\mathrm{K}, \mathrm{Cl}, \mathrm{S}$ and $\mathrm{O}$. In contrast to these regions of considerable reduced attack, severe corrosion attack (Figure 13b) which preferentially progressed towards the bulk alloy through the grain boundaries also occurred for samples preoxidized in $\mathrm{O}_{2}+10 \mathrm{vol} \% \mathrm{H}_{2} \mathrm{O}$ at $900{ }^{\circ} \mathrm{C}$. Such attack was observed on more than $80 \%$ of the sample cross section. In such regions where severe corrosion attack occurred, EDS maps (Figure 14b) reveal that the corrosion products were similar in composition, to that observed after corrosion of the sample preoxidized in $\mathrm{O}_{2}$ at $900{ }^{\circ} \mathrm{C}$ (cf. Figure 11b). 


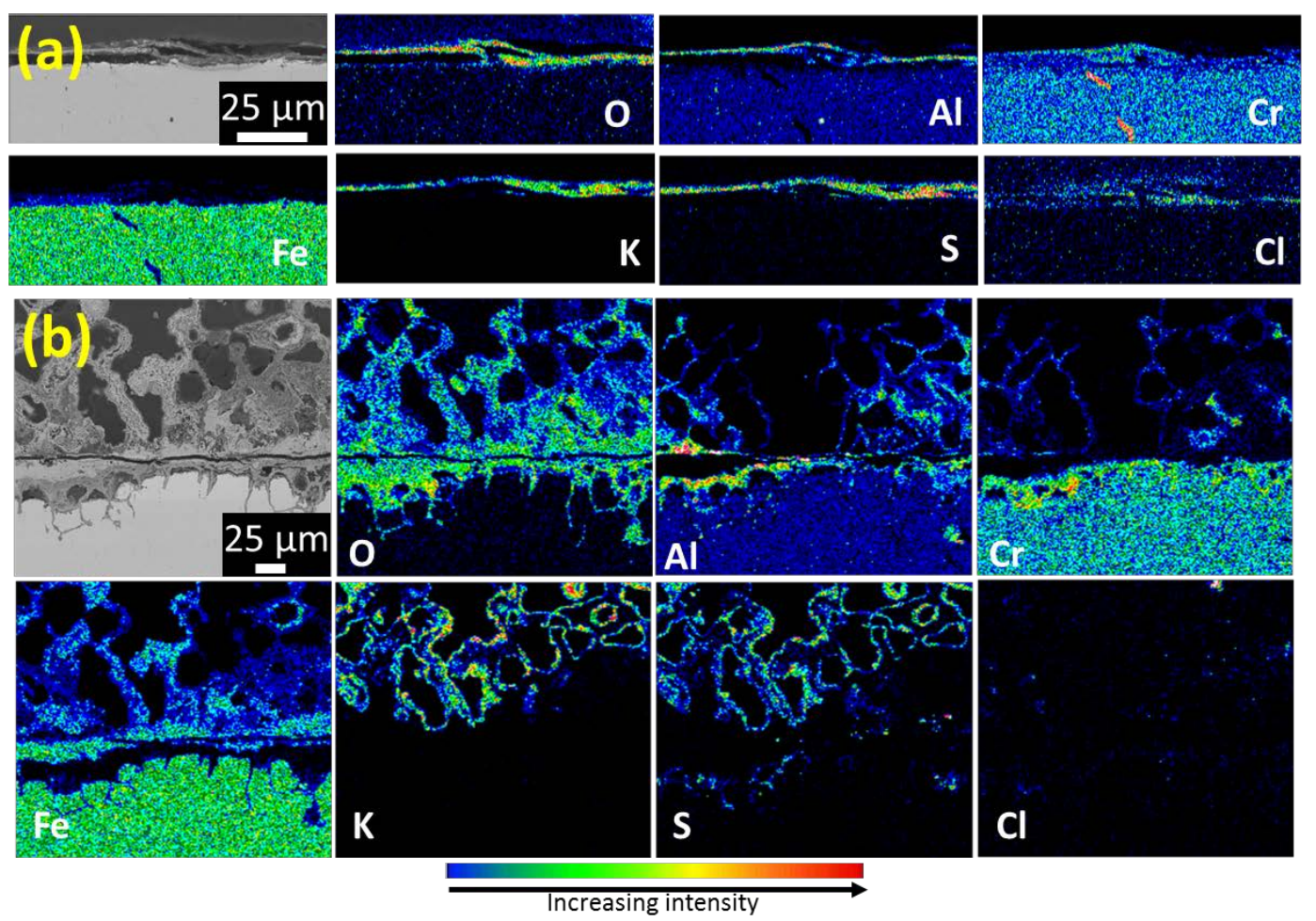

Figure 14. EDS maps showing the elemental composition of corrosion products on (a) 'non-attacked' and (b) severely attacked regions of a preoxidized sample (in $\mathrm{O}_{2}+10 \mathrm{vol} \% \mathrm{H}_{2} \mathrm{O}$ at $900{ }^{\circ} \mathrm{C}$ ) after corrosion exposure.

Although the general morphology and composition of the corrosion products on non-preoxidized samples and samples preoxidized at $900{ }^{\circ} \mathrm{C}$ (in $\mathrm{O}_{2}$ and in $\mathrm{O}_{2}+10 \mathrm{vol} \% \mathrm{H}_{2} \mathrm{O}$ ) were similar, the extent of corrosion damage differed. Based on the mean thickness of over 50 measurements on the sample cross sections (Table 2), it was observed that samples preoxidized at $900{ }^{\circ} \mathrm{C}$ (in $\mathrm{O}_{2}$ and in $\mathrm{O}_{2}+10$ vol\% $\mathrm{H}_{2} \mathrm{O}$ ) sustained less corrosion attack relative to the non-preoxidized samples.

Table 2. Mean thickness of the outward and inward growing layers of the corrosion products on nonpreoxidized samples and samples preoxidized at $900{ }^{\circ} \mathrm{C}$, after corrosion exposures.

\begin{tabular}{llc}
\hline \multirow{2}{*}{ Sample condition } & \multicolumn{2}{l}{ Thickness of corrosion products $(\mu \mathrm{m})$} \\
\cline { 2 - 3 } & Outward growing & Inward growing \\
\hline Non-preoxidized & $197 \pm 47$ & $73 \pm 16$ \\
\hline Preoxidized at $900{ }^{\circ} \mathrm{C}$ in $\mathrm{O}_{2}$ & $67 \pm 31$ & $31 \pm 16$ \\
\hline $\begin{array}{l}\text { Preoxidized at } 900{ }^{\circ} \mathrm{C} \text { in } \mathrm{O}_{2}+10 \\
\text { vol \% } \mathrm{H}_{2} \mathrm{O}\end{array}$ & $133 \pm 51$ & $45 \pm 30$ \\
& & \\
\end{tabular}




\subsubsection{Corrosion of samples preoxidized at $1100{ }^{\circ} \mathrm{C}$}

The formed $\alpha-\mathrm{Al}_{2} \mathrm{O}_{3}$-rich layer due to preoxidation in $\mathrm{O}_{2}$ at $1100{ }^{\circ} \mathrm{C}$ was still visible on the sample after corrosion (Figures 15 and 16) and obviously has protected the surface from severe corrosion attack as shown in Figure 15a. The localized regions (less than $40 \%$ of the sample) where corrosion attack occurred (Figure 15b) were close to the sample edges where the oxide layer spalled prior to corrosion exposure. The corrosion product, as shown in Figure 15b, laterally progressed underneath the preoxidation layer from the attack initiated close to the edges of the sample. From Figure 16, it is observed that the corrosion attack resulted in the formation of $\mathrm{K}_{2} \mathrm{SO}_{4}$ containing Fe and Al-rich oxide above the $\alpha-\mathrm{Al}_{2} \mathrm{O}_{3}$-rich layer, and an $\mathrm{Al}, \mathrm{Cr}$ and $\mathrm{Fe}$ containing oxide below. In the attacked grain boundaries, an enrichment of $\mathrm{Al}, \mathrm{Cr}, \mathrm{S}$ and $\mathrm{Cl}$ is observed.

Comparison of results after exposure of samples preoxidized in $\mathrm{O}_{2}$ at $1100{ }^{\circ} \mathrm{C}$ (Figure 15), with the exposure of samples preoxidized at $900{ }^{\circ} \mathrm{C}$ (Figures 11, 12 and 13) indicate that the resistance of the oxide layers to corrosion attack has been influenced by the preoxidation temperature. To check whether this effect is related to changes in the bulk microstructure due to the different preoxidation temperatures, the thermal stability of the sample bulk alloy at both $900{ }^{\circ} \mathrm{C}$ and $1100{ }^{\circ} \mathrm{C}$ was investigated with reflected light optical microscopy (not shown here) and confirmed that the bulk microstructure remained stable. Thus, the observed differences in the final corrosion attack of the various samples are solely related to the nature of the surface layers obtained by preoxidation (see section 4.3), and not induced by changes of the bulk microstructure, which could have implied different diffusion conditions during exposure.
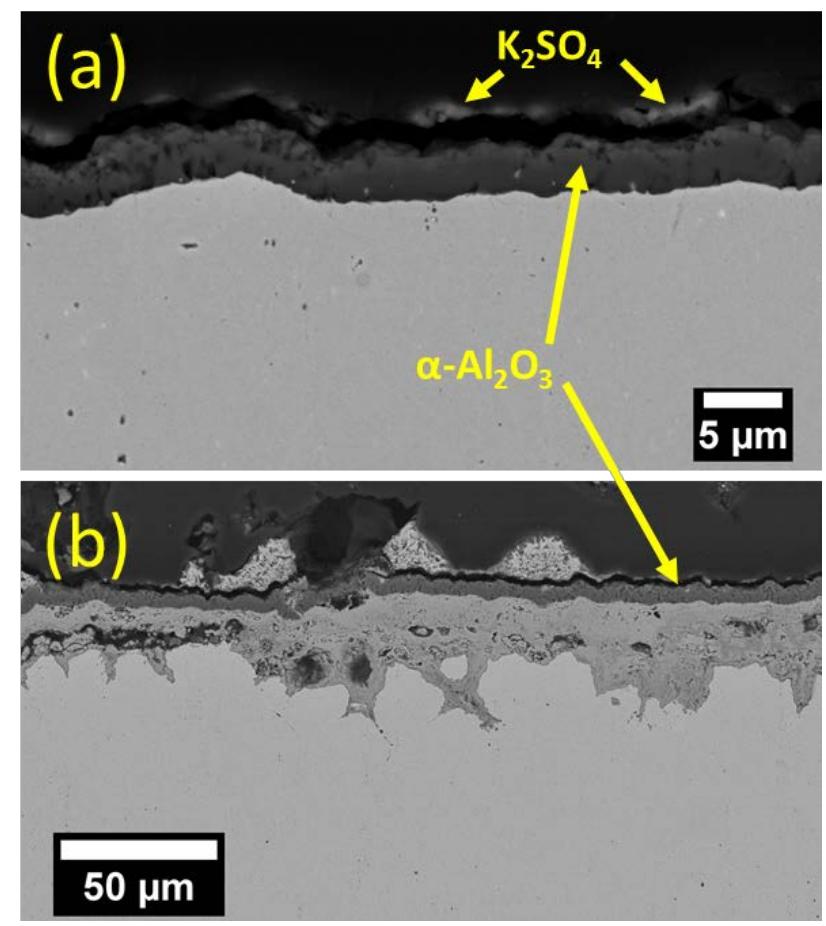

Figure 15. BSE micrographs showing microstructure of a sample preoxidized in $\mathrm{O}_{2}$ at $1100{ }^{\circ} \mathrm{C}$, after exposure. (a) Non-attacked regions are representative for most of the preoxidized sample, and (b) corrosion attack are close to positions at the sample edges. 


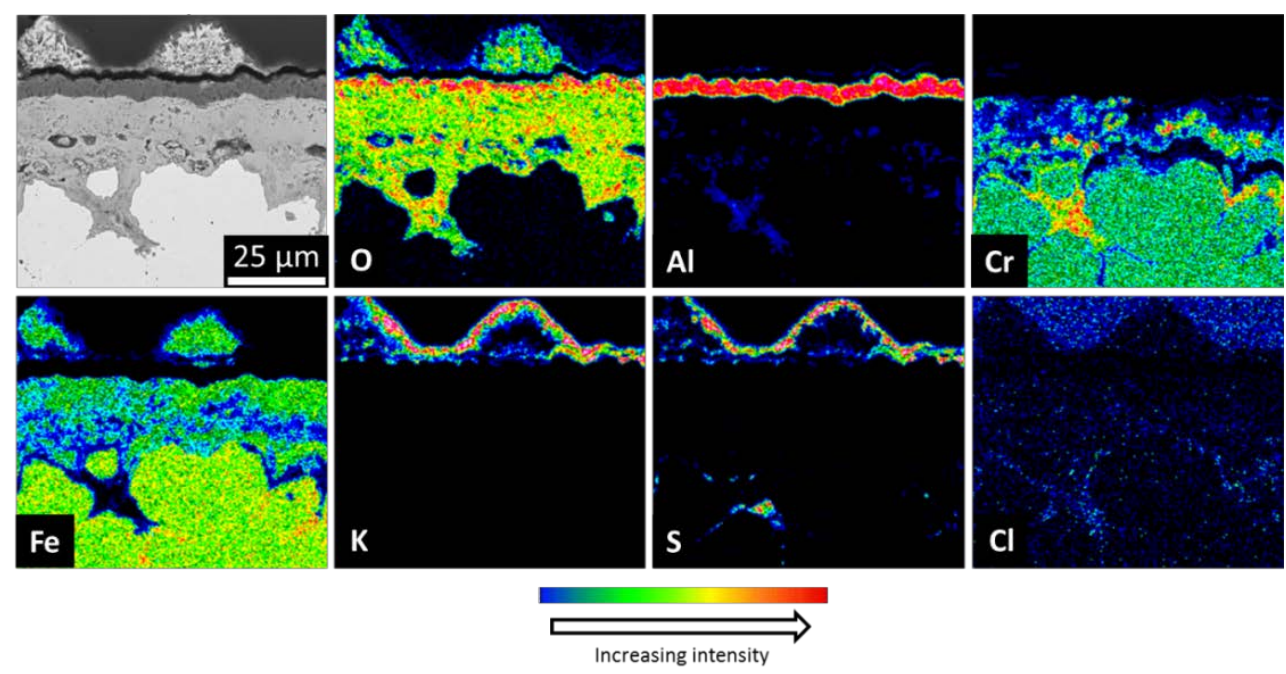

Figure 16. Elemental composition of the corrosion products on local attacked regions of a sample preoxidized in $\mathrm{O}_{2}$ at $1100{ }^{\circ} \mathrm{C}$, after corrosion exposure. Presence of $\mathrm{Cl}$ in the epoxy is responsible for its identification in the upper parts of the $\mathrm{Cl}$ map.

\section{Discussion}

\subsection{The influence of preoxidation conditions}

The $6 \mathrm{wt} \%$ of $\mathrm{Al}$ in the investigated alloy is above the minimum $\mathrm{Al}$ concentration suggested for the formation of Al-rich oxide layers on FeCrAl alloys [33] and, indeed, the formation of an Al-rich oxide layer was evident after the different preoxidation treatments (Figures 1, 3 and 4). It is well documented [19-21,24,25,33-40] that formation of any of the $\mathrm{Al}_{2} \mathrm{O}_{3}$ polymorphs ( $\alpha$-, $\gamma-, \delta$-, $\theta$-phase) is influenced by variables such as $\mathrm{H}_{2} \mathrm{O}$ in the environment, temperature and time. Earlier studies $[22,24,32]$ have reported that $\alpha-\mathrm{Al}_{2} \mathrm{O}_{3}$ formation is favoured at temperatures above $1050{ }^{\circ} \mathrm{C}$, while at lower temperatures metastable polymorphs $\left(\delta-, \gamma-, \theta-\mathrm{Al}_{2} \mathrm{O}_{3}\right)$ predominate. However, in agreement with previous investigations on FeCrAl alloys (Kanthal AF and Kanthal APMT) [19-21,38,40], XRD (Figure 5) indicated the formation of $\alpha-\mathrm{Al}_{2} \mathrm{O}_{3}$ after preoxidation of Kanthal APM already at $900{ }^{\circ} \mathrm{C}$. Nonetheless, for preoxidation at $900^{\circ} \mathrm{C}$, additional reflections from $\mathrm{Cr}_{2} \mathrm{O}_{3}$ and the tetragonal (metastable) $\mathrm{Al}_{2} \mathrm{O}_{3}$ were also recorded (Figures $5 \mathrm{~b}$ ), thus indicating that the oxide formed at $900{ }^{\circ} \mathrm{C}$ did not only consist of $\alpha-\mathrm{Al}_{2} \mathrm{O}_{3} . \mathrm{Cr}_{2} \mathrm{O}_{3}$ can be formed during the initial stages of oxidation of Crcontaining alloys $[19,21,38]$, and is known to facilitate the nucleation of $\alpha-\mathrm{Al}_{2} \mathrm{O}_{3}$ as well as the transformation of metastable $\mathrm{Al}_{2} \mathrm{O}_{3}$ polymorphs to the stable $\alpha-\mathrm{Al}_{2} \mathrm{O}_{3}[22,41]$.

As previously mentioned in section 3.1, the isomorphous lattices of $\alpha-\mathrm{Al}_{2} \mathrm{O}_{3}$ and $\mathrm{Cr}_{2} \mathrm{O}_{3}$ can allow the formation of a solid solution of the oxides. At lower temperatures, the miscibility gap in the $\mathrm{Al}_{2} \mathrm{O}_{3}-\mathrm{Cr}_{2} \mathrm{O}_{3}$ system allows for the presence of $\mathrm{Al}_{2} \mathrm{O}_{3}$ and $\mathrm{Cr}_{2} \mathrm{O}_{3}$ rich solid solutions [31,42]. The incorporation of the larger $\mathrm{Cr}^{3+}$ into the $\alpha-\mathrm{Al}_{2} \mathrm{O}_{3}$ lattice will cause an increase in its lattice cell parameter, in accordance with Vegard's law, and therefore the $\alpha-\mathrm{Al}_{2} \mathrm{O}_{3}$ peak positions will shift to lower diffraction angles if an $\alpha-\mathrm{Al}_{2} \mathrm{O}_{3}$ layer contains some amount of $\mathrm{Cr}$ [29-31]. For molar fractions 
of $\mathrm{Cr}_{2} \mathrm{O}_{3}$ higher than 0.5 , separate reflections from $\mathrm{Cr}_{2} \mathrm{O}_{3}$ will also be recorded in the diffraction pattern [29]. On the example of the 116 reflection of $\alpha-\mathrm{Al}_{2} \mathrm{O}_{3}$ at $2 \theta=91.3^{\circ}$ (Figure 5b), the high amount of $\mathrm{Cr}$ in the oxides formed at $900{ }^{\circ} \mathrm{C}$ is probably responsible for the separate 116 reflection of $\mathrm{Cr}_{2} \mathrm{O}_{3}$ at a lower $2 \theta$ value of $86.4^{\circ}$. The asymmetric profile of the $\alpha-\mathrm{Al}_{2} \mathrm{O}_{3} 116$ peak is rather attributed to the overlapping 211 reflection of $\mathrm{Cr}_{2} \mathrm{O}_{3}$, as well as reflections from the metastable $\delta$ $\mathrm{Al}_{2} \mathrm{O}_{3}$. On the basis of these observations, it is suggested that the oxides formed at $900{ }^{\circ} \mathrm{C}$ contain a Cr-rich solid solution of the stable $\alpha-\mathrm{Al}_{2} \mathrm{O}_{3}$ and $\mathrm{Cr}_{2} \mathrm{O}_{3}$, as well as the metastable $\delta-\mathrm{Al}_{2} \mathrm{O}_{3}$. The possible presence of metastable $\mathrm{Al}_{2} \mathrm{O}_{3}$ in these oxides is also supported by the platelet features observed by SEM (Figures 1b and 3b), which is the typical morphology reported for metastable polymorphs of $\mathrm{Al}_{2} \mathrm{O}_{3}[35,43,44]$. In contrast, the oxide formed at $1100{ }^{\circ} \mathrm{C}$ did not contain such platelet features, but rather exhibited globular morphologies, hence suggesting the absence of metastable $\mathrm{Al}_{2} \mathrm{O}_{3}$ in such oxides. In addition, XRD results (Figure 5a, c) suggest that these oxides are not Cr-rich. On the example of the 300 reflection of $\alpha-\mathrm{Al}_{2} \mathrm{O}_{3}$ at $2 \theta=112.9^{\circ}$ (Figure $5 \mathrm{c}$ ), a high amount of $\mathrm{Cr}$ in the oxide should have caused separate 300 reflections from $\mathrm{Cr}_{2} \mathrm{O}_{3}$ at $2 \theta=106.2^{\circ}$. Instead, a Cr-deficient solid solution of $\mathrm{Al}$-Cr-oxide, i.e. $\left(\mathrm{Al}_{0.948} \mathrm{Cr}_{0.052}\right)_{2} \mathrm{O}_{3}$, was present in the oxide and overlap between its peaks and $\alpha-\mathrm{Al}_{2} \mathrm{O}_{3}$ peaks is responsible for the asymmetric profile of the $\alpha$ $\mathrm{Al}_{2} \mathrm{O}_{3}$ peak shown in Figure 5c. The low content of $\mathrm{Cr}$ in this oxide could be due to volatilization of Cr from the oxide, which should be significant around $1100{ }^{\circ} \mathrm{C}[45,46]$.

It has been suggested that the ability of $\mathrm{H}_{2} \mathrm{O}$ to cause hydroxylation of metastable $\mathrm{Al}_{2} \mathrm{O}_{3}$ surfaces stabilizes these polymorphs against $\alpha-\mathrm{Al}_{2} \mathrm{O}_{3}$ [19]. However, on the basis of XRD and microstructural characterization (Figures 1, 3 and 5), results from the present investigation do not suggest any strong effect of $\mathrm{H}_{2} \mathrm{O}$ on delaying the transformation of metastable alumina polymorphs to stable $\alpha-\mathrm{Al}_{2} \mathrm{O}_{3}$. On the other hand, the preoxidation temperature is observed to influence the thickness and composition of the resulting oxide layer such that a thicker oxide comprising mainly of $\alpha-\mathrm{Al}_{2} \mathrm{O}_{3}$ formed after preoxidation at $1100{ }^{\circ} \mathrm{C}$ (Figures 2 and 5).

\subsection{Corrosion of non-preoxidized samples}

The porous and heterogeneous morphology of corrosion products on non-preoxidized samples of Kanthal APM (Figure 6) suggest that corrosion possibly involved vapour phase transport of species rather than transportation through the oxide lattice. It is known that $\mathrm{HCl}$ in the inlet gas mixture, in addition to that formed from conversion of the deposits to $\mathrm{K}_{2} \mathrm{SO}_{4}[6,47,48]$, is able to induce chlorination of alloying elements, causing formation of non-stable metal chlorides. Thermodynamic calculations [49,50], in line with previous investigations [51] show that chlorination of the major alloying elements in Kanthal APM (Fe, $\mathrm{Cr}$ and $\mathrm{Al}$ ) is favourable at $560{ }^{\circ} \mathrm{C}$. The high vapour partial pressures of the metal chlorides generated from the chlorination process $[14,28,52]$ is suggested to have provoked vapour phase transport of these species away from the corrosion front. This is supported by the heterogeneous and porous morphology of the corrosion products (Figures 6 and 9a). Although the investigated alloy contains about $6 \mathrm{wt} \% \mathrm{Al}$, which under oxidizing atmospheres should form a protective layer of $\mathrm{Al}_{2} \mathrm{O}_{3}$ [33], the nature of corrosion attack under biomass firing conditions prevented this. Al oxides can result from conversion of their chlorides to oxides (Figure 7), however $\mathrm{AlCl}_{3}$ is so volatile that it evaporates from the alloy before being oxidised and therefore does not 
form a compact uniform layer but instead a porous heterogeneous oxide in the corrosion products above the original metal surface.

The preferential nature of corrosion attack along the alloy grain boundaries (Figures 6 and 9b) may have been caused by faster transportation through such pathways. However, as bulk microstructural characterization of the investigated alloy showed the presence of $\mathrm{Cr}$-rich precipitates, possibly $\mathrm{Cr}$ carbides (micrographs not shown here), the preferential attack of such precipitates, owing to the sensitivity of $\mathrm{Cl}$ towards $\mathrm{Cr}$-carbides $[3,51,53,54]$, may have caused attack to progress along the grain boundaries.

Since the oxide formed from conversion of the metal chlorides is not protective, both atomic and molecular transport of sulphur towards the corrosion front is possible during corrosion. The relatively low oxygen partial pressure at such positions may allow for sulphidation attack in addition to chlorination. This probably accounts for $\mathrm{S}$ accumulation in the internally formed corrosion products (Figure 7).

\subsection{Corrosion of preoxidized samples}

From assessment of the corrosion products on samples preoxidized at $900{ }^{\circ} \mathrm{C}$ in $\mathrm{O}_{2}$ or in $\mathrm{O}_{2}+10$ vol\% $\mathrm{H}_{2} \mathrm{O}$, and at $1100{ }^{\circ} \mathrm{C}$ in $\mathrm{O}_{2}$ (cf. Figures 11, 12, 13, and 15), it is evident that the samples preoxidized at $1100{ }^{\circ} \mathrm{C}$ resisted corrosion attack to a larger degree than those preoxidized at $900{ }^{\circ} \mathrm{C}$. As was suggested in section 3.2.3, the stable bulk microstructure of the samples after the different heat treatments suggests that the difference in corrosion performance is related to the nature of the oxides obtained after the different preoxidation treatments. Specifically, the observed differences in thickness and composition of the oxides as a function of the preoxidation conditions are suggested as the main influence on the corrosion performance.

As shown in Figure 2, the type of preoxidation treatment resulted in different thickness of the oxide layers. The larger oxide thickness of samples preoxidized at $1100{ }^{\circ} \mathrm{C}$ exhibited resistance to corrosion because it physically prevented diffusion of the corrosive species through the oxide, compared to samples preoxidized at $900{ }^{\circ} \mathrm{C}$. However, the thick oxide regions on samples preoxidized at $900{ }^{\circ} \mathrm{C}$ in $\mathrm{O}_{2}+10$ vol\% $\mathrm{H}_{2} \mathrm{O}$ (Figure $4 \mathrm{e}$ ) did not offer protection against corrosion, so this consideration may not fully explain the observed trend in corrosion attack. According to results in reference [13], the oxide composition as well as its compactness, is more important than the oxide thickness with respect to the resistance of pure metals ( $\mathrm{Fe}, \mathrm{Cr}$ and $\mathrm{Ni}$ ) towards corrosion attack in Cl-containing environments. In line with this, the relatively low attack observed on samples preoxidized at $1100{ }^{\circ} \mathrm{C}$ may not solely relate to the thicker oxide, but may also originate from the observed difference in composition of this oxide, compared to the oxide obtained at $900{ }^{\circ} \mathrm{C}$.

In literature, it is noted that the initiation steps of corrosion under biomass firing conditions involves direct reaction between the corrosive species and the material (or oxide) [7,55,56]. In this respect, the reaction between $\mathrm{Cr}_{2} \mathrm{O}_{3}$-rich oxides and $\mathrm{KCl}$ depletes an alloy of $\mathrm{Cr}$ and causes the formation of a less protective Cr-depleted oxide. Considering such reaction as a criteria for initialization of corrosion attack under the conditions investigated in this study, the severe corrosion attack suffered by samples 
that were preoxidized at $900{ }^{\circ} \mathrm{C}$ (Figures 11-14) may result from reaction between $\mathrm{KCl}$ and $\mathrm{Cr}_{2} \mathrm{O}_{3}$ identified in these oxides (Figure 5). Subsequently, the less protective oxide may have allowed further ingress of corrosive species which propagated the corrosion attack. On the contrary, because the samples preoxidized at $1100{ }^{\circ} \mathrm{C}$ contained a very low amount of $\mathrm{Cr}$ in solid solution with $\alpha-\mathrm{Al}_{2} \mathrm{O}_{3}$ (Figure 5c), they did not suffer severe corrosion attack. Indeed, microstructural investigations (Figures 15 and 16) show that the $\alpha-\mathrm{Al}_{2} \mathrm{O}_{3}$ rich oxide was not attacked after the 1 week corrosion exposure. Thus both the increased thickness of this oxide and the very low content of $\mathrm{Cr}_{2} \mathrm{O}_{3}$ eliminated initiation sites for corrosion attack.

Considering also the direct reaction between $\mathrm{KCl}$ and different polymorphs of $\mathrm{Al}_{2} \mathrm{O}_{3}$, thermodynamic calculations with FactSage $[49,50]$ show that both the thermodynamically stable $\alpha-\mathrm{Al}_{2} \mathrm{O}_{3}$, and the metastable $\delta$ - $\mathrm{Al}_{2} \mathrm{O}_{3}$ polymorph will withstand corrosion attack due to the positive Gibbs free energy change $\left(\Delta \mathrm{G}^{0}\right)$ of their reactions with solid $\mathrm{KCl}$ at $560{ }^{\circ} \mathrm{C}$ (Table 3). However, according to data in literature [55], $\mathrm{KCl}$ is expected to have a vapour pressure of more than $10^{-6}$ atm at $560{ }^{\circ} \mathrm{C}$, implying that gradual volatilization of the $\mathrm{KCl}$ deposits occurs. Interestingly, thermodynamic calculations in Table 3 suggest a slightly higher driving force (a negative $\Delta \mathrm{G}^{0}$ ) for reaction between the metastable $\delta$-polymorph of $\mathrm{Al}_{2} \mathrm{O}_{3}$ and the deposit when it is in the gas phase, in contrast to the reaction with stable $\alpha-\mathrm{Al}_{2} \mathrm{O}_{3}$ (a positive $\Delta \mathrm{G}^{0}$ ).

Table 3. Gibbs free energy changes for the reactions of different alumina polymorphs with $\mathrm{KCl}$ (s, g). Calculations were performed with FactSage $[49,50]$.

\begin{tabular}{lll}
\hline & $\Delta \mathrm{G}^{0}$ at $560{ }^{\circ} \mathrm{C}$ \\
Reaction & $\left(\mathrm{kJmol}^{-1}\right.$ & $\mathrm{HCl})$ \\
& {$[49,50]$} & \\
\cline { 2 - 3 } & $\alpha$ & $\delta$ \\
\hline$\frac{1}{2} \mathrm{Al}_{2} \mathrm{O}_{3}(\mathrm{~s})+\mathrm{KCl}(\mathrm{s})+\frac{1}{2} \mathrm{H}_{2} \mathrm{O} \rightleftharpoons \mathrm{KAlO}_{2}(\mathrm{~s})+\mathrm{HCl}(\mathrm{g})$ & 101.11 & 96.92 \\
\hline$\frac{1}{2} \mathrm{Al}_{2} \mathrm{O}_{3}(\mathrm{~s})+\mathrm{KCl}(\mathrm{g})+\frac{1}{2} \mathrm{H}_{2} \mathrm{O} \rightleftharpoons \mathrm{KAlO}_{2}(\mathrm{~s})+\mathrm{HCl}(\mathrm{g})$ & 4.15 & -0.04 \\
\hline
\end{tabular}

Thus, assuming that the initiation of corrosion attack was influenced by the thermodynamic favourability of reactions between $\mathrm{KCl}(\mathrm{g})$ and the preoxidized surfaces, the severe corrosion attack suffered by samples that were preoxidized at $900{ }^{\circ} \mathrm{C}$ (Figures 11-14), which contained the metastable $\delta-\mathrm{Al}_{2} \mathrm{O}_{3}$ polymorph, corroborates the fact that the resistance of the oxide to corrosion attack is influenced by its composition.

In the event of breakdown of the preoxidized layer, it was not possible to form a new protective oxide layer during exposure (Figures 11-14) since the exposure temperature $\left(560{ }^{\circ} \mathrm{C}\right)$ is too low to support protective $\mathrm{Al}_{2} \mathrm{O}_{3}$ formation. Therefore the corrosion process almost proceeds in a manner similar to the non-preoxidized samples such that the alloying elements are chlorinated and redeposited as porous 
oxides. Moreover, as was observed for the non-preoxidized samples, the transport of S-species leading to sulphidation (Figures $11 \mathrm{~b}$ and 12c) also becomes possible by virtue of the porous morphology of the corrosion products, as well as the low oxygen partial pressure induced by the presence of Cr- and Al-rich oxides close to the corrosion front [57]. Previous investigations [9-11,58] have also suggested that sulphidation of preoxidized samples only occurs if sulphur transport is facilitated by fissures or pores in the oxide. However, comparison of the corrosion products from such studies with the present results clearly suggests that the attack by Cl-containing species is more aggressive.

\section{Conclusions}

The phase composition and thickness of $\mathrm{Al}_{2} \mathrm{O}_{3}$ formed from preoxidation of Kanthal APM varies with temperature and preoxidation environment. At the lower preoxidation temperature of $900{ }^{\circ} \mathrm{C}$, a $\mathrm{Cr}$-rich solid solution of Al-Cr-oxide was detected. Also, a metastable $\mathrm{Al}_{2} \mathrm{O}_{3}$, possibly $\delta-\mathrm{Al}_{2} \mathrm{O}_{3}$, was identified in the oxides formed at this temperature. On the contrary, preoxidation at $1100{ }^{\circ} \mathrm{C}$ in $\mathrm{O}_{2}$ leads to formation of a layer consisting mainly of the thermodynamically stable $\alpha-\mathrm{Al}_{2} \mathrm{O}_{3}$.

The corrosion attack on preoxidized Kanthal APM under conditions relevant to biomass firing is sensitive to the composition and thickness of the preoxidation layers. Thinner preoxidation layers formed in both $\mathrm{O}_{2}$ and $\mathrm{O}_{2}+10 \mathrm{vol} \% \mathrm{H}_{2} \mathrm{O}$ atmospheres at $900{ }^{\circ} \mathrm{C}$ containing a solid solution of $\mathrm{Al}$ with high amounts of $\mathrm{Cr}$ in the oxide as well as a metastable $\delta-\mathrm{Al}_{2} \mathrm{O}_{3}$, suffer corrosion attack. Oxide layers formed at $1100{ }^{\circ} \mathrm{C}$ in $\mathrm{O}_{2}$, containing mainly $\alpha-\mathrm{Al}_{2} \mathrm{O}_{3}$ are resistant to corrosion attack. In this regard, the preoxidation temperature, is more important than the preoxidation atmosphere with respect to corrosion resistance.

Corrosion attack does not occur on mechanically stable $\alpha-\mathrm{Al}_{2} \mathrm{O}_{3}$ after 1 week exposure to conditions simulating biomass firing.

In the absence of a protective layer on Kanthal APM, the alloy suffers severe corrosion attack under biomass firing conditions. Protective Al-oxides cannot form under such conditions, instead porous, heterogeneous and non-protective corrosion products form due to volatile species involved in the corrosion attack.

\section{Acknowledgements}

This work is part of the Danish Strategic Research Centre, Power Generation from Renewable Energy (GREEN). The authors acknowledge funding from the Danish council for Strategic Research.

\section{References}

[1] F.J. Frandsen, Ash Formation, Deposition and Corrosion when Utilizing Straw for Heat and Power Production, Dr. Techn. Thesis, Department of Chemical and Biochemical Engineering, Technical Univeristy of Denmark. ISBN: 9788792481405, Kongens Lyngby, 2011.

[2] S.B. Hansen, P.A. Jensen, F.J. Frandsen, H. Wu, M.S. Bashir, J. Wadenbäck, B. Sander, P. 
Glarborg, Deposit Probe Measurements in Large Biomass-Fired Grate Boilers and Pulverized-Fuel Boilers, Energy \& Fuels. 28 (2014) 3539-3555.

[3] M. Montgomery, A. Karlsson, O.H. Larsen, Field test corrosion experiments in Denmark with biomass fuels. Part 1: Straw-firing, Mater. Corros. 53 (2002) 121-131.

[4] M. Montgomery, A. Karlsson, In-situ corrosion investigation at Masnedø CHP plant - a straw-fired power plant, Mater. Corros. 50 (1999) 579-584.

[5] J. Pettersson, H. Asteman, J.-E. Svensson, L.-G. Johansson, KCl Induced Corrosion of a 304type Austenitic Stainless Steel at $600^{\circ} \mathrm{C}$; The Role of Potassium, Oxid. Met. 64 (2005) 2341.

[6] H.P. Nielsen, F.J. Frandsen, K. Dam-Johansen, Lab-Scale Investigations of HighTemperature Corrosion Phenomena in Straw-Fired Boilers, Energy \& Fuels. 13 (1999) 11141121.

[7] R.A. Antunes, M.C.L. de Oliveira, Corrosion in biomass combustion: A materials selection analysis and its interaction with corrosion mechanisms and mitigation strategies, Corros. Sci. 76 (2013) 6-26.

[8] H.J. Grabke, E. Reese, M. Spiegel, The effects of chlorides, hydrogen chloride, and sulfur dioxide in the oxidation of steels below deposits, Corros. Sci. 37 (1995) 1023-1043.

[9] S. Sheybany, D.L. Douglass, The effect of preoxidation of some Ni, Fe, and Co-Base alloys on subsequent sulfidation at 982 oC in sulfur vapor, Oxid. Met. 30 (1988) 433-463.

[10] M.F. Pillis, L.V. Ramanathan, Effect of pre-oxidation on high temperature sulfidation behavior of FeCr and FeCrAl alloys, Mater. Res. 7 (2004) 97-102.

[11] F.H. Stott, M.F. Chong, The transport of sulphur through preformed Al2O3 scales on ironbase alloys in environments of high sulphur and low oxygen activities pertinent to coal conversion processes at high temperature, Solid State Ionics. 12 (1984) 493-503.

[12] M.F. Stroosnijder, V. Guttmann, H. Buscail, J.H.W. de Wit, The effect of pre-oxidation and the influence of deformation on the corrosion behaviour of two heat resistant steels in a sulphur-oxygen-carbon bearing environment, Corros. Sci. 36 (1994) 207-219.

[13] H. Asteman, M. Spiegel, Investigation of the $\mathrm{HCl}$ (g) attack on pre-oxidized pure Fe, Cr, Ni and commercial 304 steel at $400^{\circ} \mathrm{C}$, Corros. Sci. 49 (2007) 3626-3637.

[14] P. Viklund, R. Pettersson, HCl-Induced High Temperature Corrosion of Stainless Steels in Thermal Cycling Conditions and the Effect of Preoxidation, Oxid. Met. 76 (2010) 111-126.

[15] J. Lehmusto, P. Yrjas, M. Hupa, The Effect of Pretreatment on the Corrosion Resistance of Superheater Materials, Solid State Phenom. 227 (2015) 309-312.

[16] N. Israelsson, J. Engkvist, K. Hellström, M. Halvarsson, J.-E. Svensson, L.-G. Johansson, $\mathrm{KCl}$-Induced Corrosion of an FeCrAl Alloy at $600{ }^{\circ} \mathrm{C}$ in $\mathrm{O} 2+\mathrm{H} 2 \mathrm{O}$ Environment: The Effect of Pre-oxidation, Oxid. Met. 83 (2015) 29-53.

[17] K. Hellström, J. Hall, P. Malmberg, Y. Cao, M. Norell, J.-E. Svensson, Mitigation of Fireside 
Corrosion in Power Plants: The Combined Effect of Sulfur Dioxide and Potassium Chloride on the Corrosion of a FeCrAl Alloy, Energy \& Fuels. 28 (2014) 6116-6129.

[18] S. Kiamehr, K. V Dahl, T.N. Lomholt, T.L. Christiansen, M.A.J. Somers, High Temperature Corrosion due to Biomass Firing: A Study on the Reactivity between Potassium Chloride and Oxides, in: Int. Symp. High-Temperature Oxid. Corros., The Iron and Steel Institute of Japan, Hokkaido, 2014: pp. 144-147.

[19] H. Götlind, F. Liu, J.-E. Svensson, M. Halvarsson, L.-G. Johansson, The Effect of Water Vapor on the Initial Stages of Oxidation of the FeCrAl Alloy Kanthal AF at $900{ }^{\circ} \mathrm{C}$, Oxid. Met. 67 (2007) 251-266.

[20] H. Josefsson, F. Liu, J.-E. Svensson, M. Halvarsson, L.-G. Johansson, Oxidation of FeCrAl alloys at $500-900^{\circ} \mathrm{C}$ in dry O2, Mater. Corros. 56 (2005) 801-805.

[21] J. Engkvist, S. Canovic, K. Hellström, A. Järdnäs, J.-E. Svensson, L.-G. Johansson, M. Olsson, M. Halvarsson, Alumina Scale Formation on a Powder Metallurgical FeCrAl Alloy (Kanthal APMT) at $900-1,100{ }^{\circ} \mathrm{C}$ in Dry O2 and in O2 + H2O, Oxid. Met. 73 (2010) 233253.

[22] H.J. Grabke, M.W. Brumm, B. Wagemann, The Oxidation of NiAl, Mater. Corros. Und Korrosion. 47 (1996) 675-677.

[23] R. Janakiraman, G.H. Meier, F.S. Pettit, The effect of water vapor on the oxidation of alloys that develop alumina scales for protection, Metall. Mater. Trans. A. 30 (1999) 2905-2913.

[24] F.H. Stott, G.C. Wood, J. Stringer, The influence of alloying elements on the development and maintenance of protective scales, Oxid. Met. 44 (1995) 113-145.

[25] D.J. Young, Effects of Water Vapour on Oxidation, in: Corros. Ser., Elsevier, 2008: pp. 455495.

[26] T. Dudziak, M. Łukaszewicz, N. Simms, J.R. Nicholls, Steam oxidation of TP347HFG, super $304 \mathrm{H}$ and HR3C - analysis of significance of steam flowrate and specimen surface finish, Corros. Eng. Sci. Technol. 50 (2015) 272-282.

[27] S.C. Okoro, M. Montgomery, F.J. Frandsen, K. Pantleon, Effect of Water Vapor on HighTemperature Corrosion under Conditions Mimicking Biomass Firing, Energy \& Fuels. 29 (2015) 5802-5815.

[28] S.C. Okoro, M. Montgomery, F.J. Frandsen, K. Pantleon, High Temperature Corrosion under Laboratory Conditions Simulating Biomass-Firing: A Comprehensive Characterization of Corrosion Products, Energy \& Fuels. 28 (2014) 6447-6458.

[29] M. Ristić, S. Popović, S. Musić, Structural properties of the system Al2O3-Cr2O3, Mater. Lett. 16 (1993) 309-312.

[30] J. Graham, Lattice spacings and colour in the system alumina-chromic oxide, J. Phys. Chem. Solids. 17 (1960) 18-25.

[31] F. Bondioli, A.M. Ferrari, C. Leonelli, T. Manfredini, L. Linati, P. Mustarelli, Reaction Mechanism in Alumina/Chromia (Al2O3-Cr2O3) Solid Solutions Obtained by 
Coprecipitation, J. Am. Ceram. Soc. 83 (2004) 2036-2040.

[32] I. Levin, D. Brandon, Metastable Alumina Polymorphs: Crystal Structures and Transition Sequences, J. Am. Ceram. Soc. 81 (2005) 1995-2012.

[33] J. Engkvist, U. Bexell, M. Grehk, M. Olsson, High temperature oxidation of FeCrAl-alloys influence of Al-concentration on oxide layer characteristics, Mater. Corros. 60 (2009) 876881.

[34] H. Buscail, S. Heinze, P. Dufour, J.P. Larpin, Water-vapor-effect on the oxidation of Fe-21.5 wt.\%Cr-5.6 wt.\%Al at $1000^{\circ} \mathrm{C}$, Oxid. Met. 47 (1997) 445-464.

[35] H.E. Kadiri, R. Molins, Y. Bienvenu, M.F. Horstemeyer, Abnormal High Growth Rates of Metastable Aluminas on FeCrAl Alloys, Oxid. Met. 64 (2005) 63-97.

[36] W.J. Quadakkers, D. Naumenko, E. Wessel, V. Kochubey, Growth Rates of Alumina Scales on $\mathrm{Fe}-\mathrm{Cr}-\mathrm{Al}$ Alloys, Oxid. Met. 61 (2004) 17-37.

[37] S. Canovic, J. Engkvist, F. Liu, H. Lai, H. Götlind, K. Hellström, J.-E. Svensson, L.-G. Johansson, M. Olsson, M. Halvarsson, Microstructural Investigation of the Initial Oxidation of the FeCrAlRE Alloy Kanthal AF in Dry and Wet $\mathrm{O} 2$ at 600 and $800^{\circ} \mathrm{C}$, J. Electrochem. Soc. 157 (2010) C223.

[38] K. Hellström, N. Israelsson, M. Halvarsson, S. Canovic, J.-E. Svensson, L.-G. Johansson, The Oxide Scales Formed on a Dispersion-Strengthened Powder Metallurgical FeCrAl Alloy at $900{ }^{\circ} \mathrm{C}$ in $\mathrm{O} 2$ and in $\mathrm{O} 2+\mathrm{H} 2 \mathrm{O}$, Oxid. Met. 84 (2015) 1-19.

[39] K. Hellström, N. Israelsson, N. Mortazavi, S. Canovic, M. Halvarsson, J.-E. Svensson, L.-G. Johansson, Oxidation of a Dispersion-Strengthened Powder Metallurgical FeCrAl Alloy in the Presence of $\mathrm{O} 2$ at $1,100{ }^{\circ} \mathrm{C}$ : The Influence of Water Vapour, Oxid. Met. 83 (2015) 533558.

[40] F. Liu, H. Götlind, J.-E. Svensson, L.-G. Johansson, M. Halvarsson, Early stages of the oxidation of a FeCrAlRE alloy (Kanthal AF) at $900^{\circ} \mathrm{C}$ : A detailed microstructural investigation, Corros. Sci. 50 (2008) 2272-2281.

[41] M.W. Brumm, H.J. Grabke, The oxidation behaviour of NiAl-I. Phase transformations in the alumina scale during oxidation of NiAl and NiAl-Cr alloys, Corros. Sci. 33 (1992) 16771690.

[42] M. Fujita, K. Inukai, S. Sakida, T. Nanba, J. Ommyoji, A. Yamaguchi, Y. Miura, Sintering of Al2O3-Cr2O3 Powder Prepared by Sol-Gel Process, J. Soc. Mater. Sci. Japan. 56 (2007) 526-530.

[43] S. Chevalier, A. Galerie, O. Heintz, R. Chassagnon, A. Crisci, Thermal Alumina Scales on FeCrAl: Characterization and Growth Mechanism, Mater. Sci. Forum. 595-598 (2008) 915922.

[44] R. Chegroune, E. Salhi, A. Crisci, Y. Wouters, A. Galerie, On the Competitive Growth of Alpha and Transient Aluminas During the First Stages of Thermal Oxidation of FeCrAl Alloys at Intermediate Temperatures, Oxid. Met. 70 (2008) 331-337. 
[45] E.J. Opila, N.S. Jacobson, D.L. Myers, E.H. Copland, Predicting oxide stability in hightemperature water vapor, JOM. 58 (2006) 22-28.

[46] C.S. Tedmon, The Effect of Oxide Volatilization on the Oxidation Kinetics of Cr and Fe-Cr Alloys, J. Electrochem. Soc. 113 (1966) 766.

[47] L.W. Sengeløv, T.B. Hansen, C. Bartolome, H. Wu, K.H. Pedersen, F.J. Frandsen, A.D. Jensen, P. Glarborg, Sulfation of Condensed Potassium Chloride by SO 2, Energy \& Fuels. 27 (2013) 3283-3289.

[48] S.C. Van Lith, F.J. Frandsen, M. Montgomery, T. Vilhelmsen, S.A. Jensen, Lab-scale Investigation of Deposit-induced Chlorine Corrosion of Superheater Materials under Simulated Biomass-firing Conditions. Part 1: Exposure at $560{ }^{\circ} \mathrm{C}$, Energy \& Fuels. 59 (2009) 3457-3468.

[49] What's New in FactSage 7.0, (2015). http://www.crct.polymtl.ca/fact/facthelp/FS70New.htm (accessed June 2, 2016).

[50] C.W. Bale, E. Bélisle, P. Chartrand, S.A. Decterov, G. Eriksson, K. Hack, I.-H. Jung, Y.-B. Kang, J. Melançon, A.D. Pelton, C. Robelin, S. Petersen, FactSage thermochemical software and databases — recent developments, Calphad. 33 (2009) 295-311.

[51] A. Zahs, M. Spiegel, H. Grabke, The influence of alloying elements on the chlorine-induced high temperature corrosion of Fe-Cr alloys in oxidizing atmospheres, Mater. Corros. 50 (1999) 561-578.

[52] R. Bender, M. Schütze, The role of alloying elements in commercial alloys for corrosion resistance in oxidizing-chloridizing atmospheres part I: Literature evaluation and thermodynamic calculations on phase stabilities, Mater. Corros. 54 (2003) 567-586.

[53] H.J. Grabke, M. Spiegel, A. Zahs, Role of alloying elements and carbides in the chlorineinduced corrosion of steels and alloys, Mater. Res. 7 (2004) 89-95.

[54] M.A. Uusitalo, R. Backman, L.-M. Berger, P.M.J. Vuoristo, T.A. Mäntylä, Oxidation resistance of carbides in chlorine-containing atmospheres, High Temp. Mater. Process. 21 (2002) 307-320.

[55] J. Pettersson, N. Folkeson, L.-G. Johansson, J.-E. Svensson, The Effects of KCl, K2SO4 and K2CO3 on the High Temperature Corrosion of a 304-Type Austenitic Stainless Steel, Oxid. Met. 76 (2011) 93-109.

[56] J. Sui, J. Lehmusto, M. Bergelin, M. Hupa, The Effects of $\mathrm{KCl}, \mathrm{NaCl}$ and $\mathrm{K} 2 \mathrm{CO} 3$ on the High-Temperature Oxidation Onset of Sanicro 28 Steel, Oxid. Met. 85 (2016) 565-598.

[57] T. Gheno, B. Gleeson, On the Hot Corrosion of Nickel at $700{ }^{\circ} \mathrm{C}$, Oxid. Met. 84 (2015) 567584.

[58] P.S. Sidky, M.G. Hocking, The effect of pre-oxidation and thermal cycling on the corrosion behaviour of Fe-Cr-Al-based alloys in a coal gasifier atmosphere, Corros. Sci. 29 (1989) $735-765$. 